\title{
Aptamers: novelty tools for cancer biology
}

Review

\author{
Ricardo L. Pereira ${ }^{1}$, Isis C. Nascimento ${ }^{1}$, Ana P. Santos ${ }^{1}$, Isabella E.Y. Ogusuku ${ }^{1}$, \\ Claudiana Lameu ${ }^{1}$, Günter Mayer ${ }^{2,3}$ and Henning Ulrich ${ }^{1}$ \\ ${ }^{1}$ Department of Biochemistry, Institute of Chemistry, University of São Paulo, São Paulo, SP 05508-900, Brazil \\ ${ }^{2}$ Chemical Biology and Chemical Genetics, Life and Medical Sciences (LIMES) Institute, University of Bonn, 53121, Bonn, \\ Germany \\ ${ }^{3}$ Center of Aptamer Research and Development (CARD), University of Bonn, 53121, Bonn, Germany
}

Correspondence to: Henning Ulrich, email: henning@iq.usp.br

Keywords: aptamers; Cell-SELEX; clinical application; cancer

Received: September 27, $2017 \quad$ Accepted: March 22, $2018 \quad$ Published: June 01, 2018

Copyright: Pereira et al. This is an open-access article distributed under the terms of the Creative Commons Attribution License 3.0 (CC BY 3.0), which permits unrestricted use, distribution, and reproduction in any medium, provided the original author and source are credited.

\section{ABSTRACT}

\begin{abstract}
Although the term 'cancer' was still over two thousand years away of being coined, the first known cases of the disease date back to about 3000BC, in ancient Egypt. Five thousand years later, still lacking a cure, it has become one of the leading causes of death, killing over half a dozen million people yearly. So far, monoclonal antibodies are the most successful immune-therapy tools when it comes to fighting cancer. The number of clinical trials that use them has been increasing steadily during the past few years, especially since the Food and Drug Administration greenlit the use of the first immune-checkpoint blockade antibodies. However, albeit successful, this approach does come with the cost of auto-inflammatory toxicity. Taking this into account, the development of new therapeutic reagents with low toxicity becomes evident, particularly ones acting in tandem with the tools currently at our disposal. Ever since its discovery in the early nineties, aptamer technology has been used for a wide range of diagnostic and therapeutic applications. With similar properties to those of monoclonal antibodies, such as high-specificity of recognition and high-affinity binding, and the advantages of being developed using in vitro selection procedures, aptamers quickly became convenient building blocks for the generation of multifunctional constructs. In this review, we discuss the steps involved in the in vitro selection process that leads to functional aptamers - known as Systematic Evolution of Ligands by Exponential Enrichment - as well as the most recent applications of this technology in diagnostic and treatment of oncological illnesses. Moreover, we also suggest ways to improve such use.
\end{abstract}

\section{INTRODUCTION}

Over the past few years, cancer has become one of the most important endemic health issues in the world $[1,2]$. According to the World Health Organization, annual cancer cases are estimated to increase from 14 million in 2012 to more than 20 million by 2025 [3]. Not only due to its seriousness, but also due to the fact that it can have several different triggers - viral infection, environmental factors or genetic abnormalities - which lead its to different levels of aggressiveness and/or progression [4]. Its level of complexity is paired only to that of its interest as a subject of study. The very same factors that may lead to its erratic behavior, challenge scientists throughout the world to come up with tools for histopathological evaluation in order to identify cancer cells among healthy ones, thanks to the different surface receptors that both cell types present. These receptors allow for the detection of cancer cells and its prognosis, as well as determining disease progression $[5,6]$. 
Another important factor to consider is the proteome. Even though cancer has a strong link with the genome, the correlation of specific phenotypes to individual genotypes is key to leveraging the use of model organisms and patient samples in cancer research. In fact, cancer processes are mainly originated by damage or mutation of proto-oncogenes that code for proteins related to cell proliferation and differentiation, as well as the production of signals related to growth and apoptosis. Tumor development requires alterations in both oncogenes and tumor suppressor genes. These are favored by mutations in tumor susceptibility genes, which code for proteins related to DNA damage [7, 8]. This way, and because the proteome is much more dynamic, it is a more accurate source of information regarding what is happening inside the cell and, therefore, a crucial tool regarding the disease itself and, of course, its progression. Furthermore, protein markers can be detected in body fluids and tissues, making them remarkable biomarkers, since their evaluation is noninvasive and usually wellaccepted by patients [9]. In the light of such concern, a novel therapeutic approach of immunotherapy has been developed in the past few years. Even though there is not enough long-term survival data available to make a strong statement regarding its efficiency, its practicality has made sufficient impact for one to realize that it has, indeed, redefined the standard-of-care treatment in the first-line settings [10].

Apart from surgery, the major therapeutic approaches for cancer are chemotherapy and biotherapy the latter being a more biological approach, which includes immunotherapy and drug-delivery - and, given their versatility, aptamers can have an impact on both. Whether as stand-alone tools or in tandem with existing approaches, aptamers can be used both in treatment and diagnostics of oncologic illnesses with significant success.

Combinatorial chemistry is one of the most promising tools at the disposal of the pharmaceutical industry. In a glance, its use consists of three steps: synthesizing a new and random molecular library; selection against a specific target; and finally, characterizing the newly formed ligandtarget complex. Nucleic acids are compounds of interest in this field, not only because they fold into well-defined secondary and tertiary structures, but also because they are rather easy to synthesize [11]. With that in mind, in 1990, Tuerk, Gold, Ellington and Szostak developed a technique that allows the isolation of nucleic acid molecules from a library with over $10^{15}$ sequences. This technique was then called Systematic Evolution [12]. SELEX (also referred to as in vitro selection or in vitro evolution) is a combinatorial chemistry technique used to produce oligonucleotides of either RNA or single-stranded DNA that bind to a particular target with high degrees of selectivity and affinity $[13,14]$. Aptamers have been selected against a variety of targets aptamers (from aptus, the including small molecules such as ATP [15] and adenosine [16, 17], and proteins such as prions [18], as well as for inhibition of pathogenic vascular endothelial growth fator-induced (VEGF-induced) neovascularization [19].

Since the inception of this technique, both DNA and RNA aptamers have been selected against various targets - ions, small molecules or membrane receptors and even entire cells and organisms - and have demonstrated both affinity and specificity that pairs with that of monoclonal antibodies [20, 21].

Both monoclonal antibodies and combinatorial synthesized aptamers are being developed as sitespecific drugs that bind specific proteins revealing altered activities in disease states. Antibodies have been considered promising therapeutic agents in various fields, especially cancer-related ones [22]. Aptamers have been conquering a solid reputation as an excellent alternative, given their high-specificity of recognition and highaffinity binding. Plus they have singular advantages such as in vitro development, the possibility of being developed against almost every target, no need for in vivo selection during their development, and the ability to be truncated to small biological-active sequences and modified for optimization $[19,23,24]$. In addition to their discriminative recognition, aptamers offer advantages over antibodies as they can be engineered completely in a test tube, are readily produced by chemical synthesis, possess desirable storage properties, eliciting little or no immunogenicity in therapeutic applications. All this makes them promising affinity ligands and distinct tools as affinity probes and analytical and therapeutic reagents [25-28].

Aptamers are usually created by selecting them from a large random sequence pool, however, it is possible to find them in their "natural form" in riboswitches.

Non-modified aptamers are cleared rapidly from the bloodstream, with a half-life of minutes to hours, mainly due to nuclease degradation and clearance from the body by the kidneys, a result of the aptamer's inherently low molecular weight [24]. This rapid clearance, alongside the already mentioned high selectivity and affinity, represent advantages in applications such as in vivo diagnostic imaging. Their high binding affinity and specificity, among other characteristics, has made them attractive diagnostic applications to target intra- and extracellular components of key signaling pathways. One such example is the already known RNA aptamer against the epidermal growth factor receptor (EGFR), which allows detection and/or determination of the extent of glioblastoma multiforme [30]. In fact, their reputation has been growing immensely in the past few years and they are considered promising tools in the treatment of various pathologies [30], and some are actually undergoing pre-clinical trials [31]. 


\section{SELEX}

Typically, the SELEX process is an iterative one; the selection of sequences that will bind to the target takes place after a few repetitions of the selection process, with increasing stringent conditions.

The starting point of the SELEX technique is the synthesis of a library of single-stranded DNA (ssDNA) containing $10^{15}$ different sequences, each one with a random region with 16 to 75 positions flanked by two constant regions, where primer annealing occurs.

The ssDNA is then folded and then exposed to its target in order to select the sequences that constitute the desired aptamers. The ssDNA pool is incubated with its target and the best fitting molecules are collected and amplified using PCR procedures. Reiterative SELEX rounds are performed with increasing stringency to ensure the identification of the binders with the highest affinity [23].

It is, in its essence, an evolutionary process consisting in variation, selection, and replication [12], which can take up to 20 cycles to obtain the desired affinity [32].

Based on their three-dimensional structure, aptamers can bind to a wide range of targets by Watson-Crick basepairing, Hodgsteen-type or reverse type of base pairing, Van der Waals, hydrogen bonding, and electrostatic interactions [33, 34]. The specific loops are responsible for the interaction with the target (Figure 1).

In order to select the desired aptamers, the starting library of nucleic acids is incubated with the target molecule of interest. The nucleic acid ligands that adopt conformations allowing them to bind to the specific target are partitioned by filtration using either nitrocellulose (for protein target) or affinity chromatography (normally for small molecules target). The molecules that bind the target are eluted and amplified by RT-PCR (for RNA libraries) or PCR (for DNA libraries). This step yields a new pool that contains more target binding species.

Being an iterative process, the methodology used to select the desired sequences has to be repeated several times (Figure 2A). The number of cycles required to obtain functional sequences depends on the stringency imposed to each round as well as on the affinity between the target and the aptamers (Figure 2B). Once the selection process is completed, an oligonucleotide population dominated by target-binding sequences is obtained. Cloning and sequencing of the selected clones will reveal the sequence and allow predicting the structure of the selected ligands.

\section{APTAMERS, CELL-SELEX AND CANCER CELLS}

Early diagnosis and efficient eradication of tumor cells with minimum side effects on healthy cells are two of the top oncological challenges. Identification of biomarkers and targets exclusively (or differentially) expressed by tumor cells represent a significant contribution to determining prognosis, prediction of response to treatment, monitoring disease progression, development of new therapeutic and diagnostic strategies [35]. In an attempt to differentiate the molecular signature of tumor cells, several studies have used cell-SELEX technology to perform in vitro selection of aptamers against whole living cells. One of its advantages is that it does not require any previous knowledge regarding the target, thus eliminating the need to use the purified target during the procedure, which, in its natural environment, would yield aptamers against the native conformation of the target molecule.

The cell-SELEX procedure consists in the incubation of a target cell with random oligonucleotides (ssDNA or RNA), followed by the removal of the unbound aptamers and elution of aptamers bound to the cells, which are subsequently amplified and used in the next round of selection. This process is repeated several times until aptamers with high affinity and specificity are obtained. To increase their specificity, rounds of negative selection (also called counter or subtractive SELEX) are included. The pool of aptamers is incubated with cells morphologically, biologically and/or biochemically similar to the target. This can (and often is) also be done using the matrix where the target (or the aptamer) is fixed [1, 36]. To increase the efficiency of the process and to obtain aptamers with greater affinity for the target, it is advised to increase the stringency after the initial cycles. This can be attained by reducing the concentration of the target and increasing the concentration of the oligonucleotides in use, thus increasing the competition amongst the sequences. On the other hand, in negative cycles, it is suggested to use five to ten times more cells [37-40]. Some studies suggest that an automatic microfluidic system (on-chip cellSELEX) can make the process faster and more efficient [41-43].

A variant of the cell-SELEX technique - the recently described isogenic cell-SELEX (iCell-SELEX) - proposes the use of genetic manipulation in order to enhance the positive and negative selection process. The overexpression of the target protein in the cells should, in theory, increase the effectiveness of positive selection rounds. On the other hand, using cells in negative selection rounds, whose expression of the target protein has been silenced, should increase their effectiveness [44]. This approach seems to be rather interesting regarding the selection of aptamer in the natural environment of the target protein, but can only be applied to known targets.

The cell-SELEX approach has generated several aptamers against various types of tumors including lung [45], glioblastoma [46], pancreas [47-49], colorectal [43] and liver cancer [50], lymphoma [51], leukemia and others [52-54]. Among other proposals for the use of aptamers in oncological diseases are the discoveries of new biomarkers 

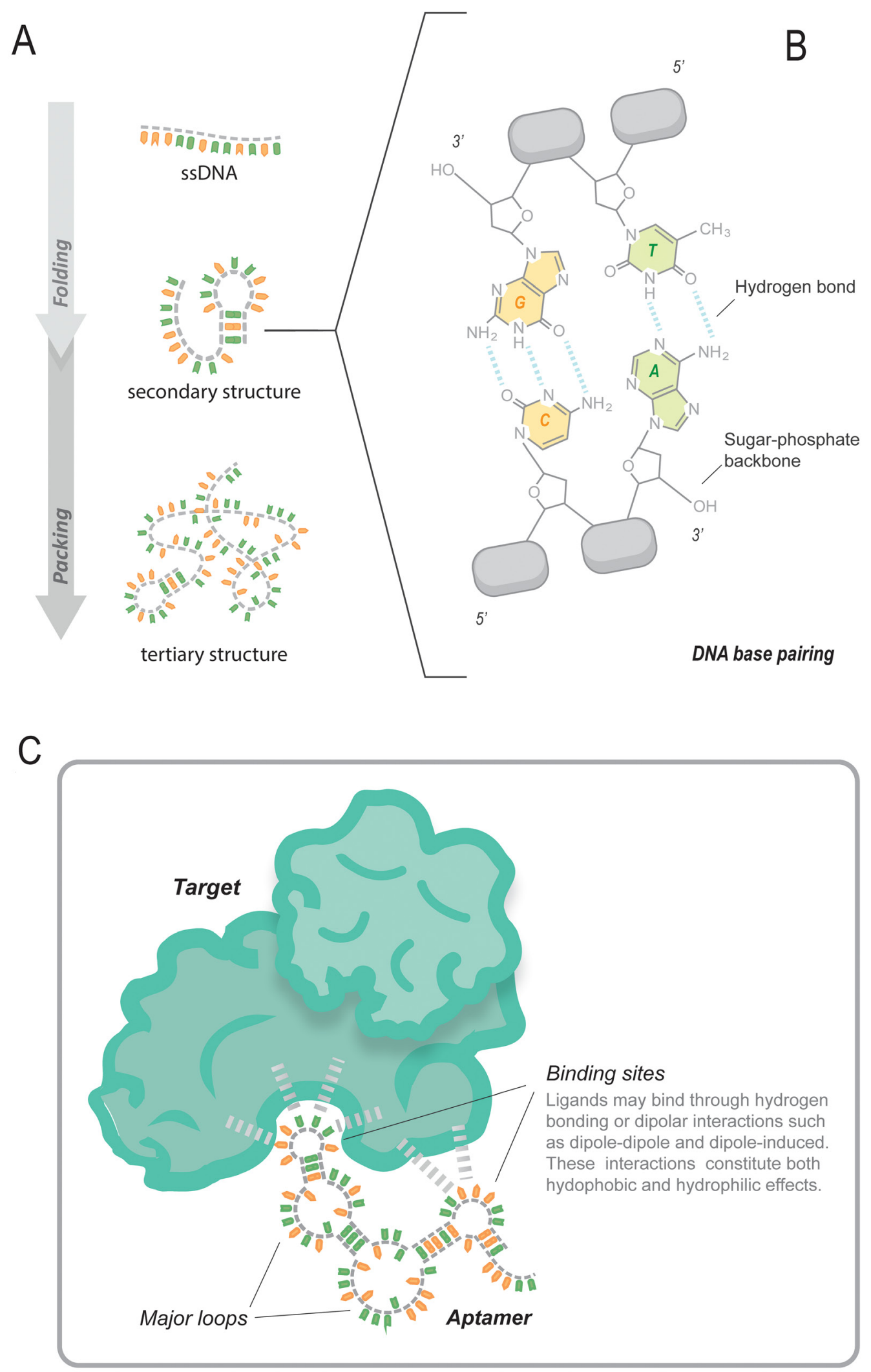

Figure 1: Depiction of the aptamer structure and its interaction with the target. (A) The ssDNA is subjected to a set of conditions that enable it to fold and adopt a secondary structure. (B) The ssDNA base pairs in the linear parts of the molecule interact via hydrogen bonds, (C) in the loops, however, the bases are free to interact with the targets and do so via hydrogen bonds and/or dipolar interactions. 

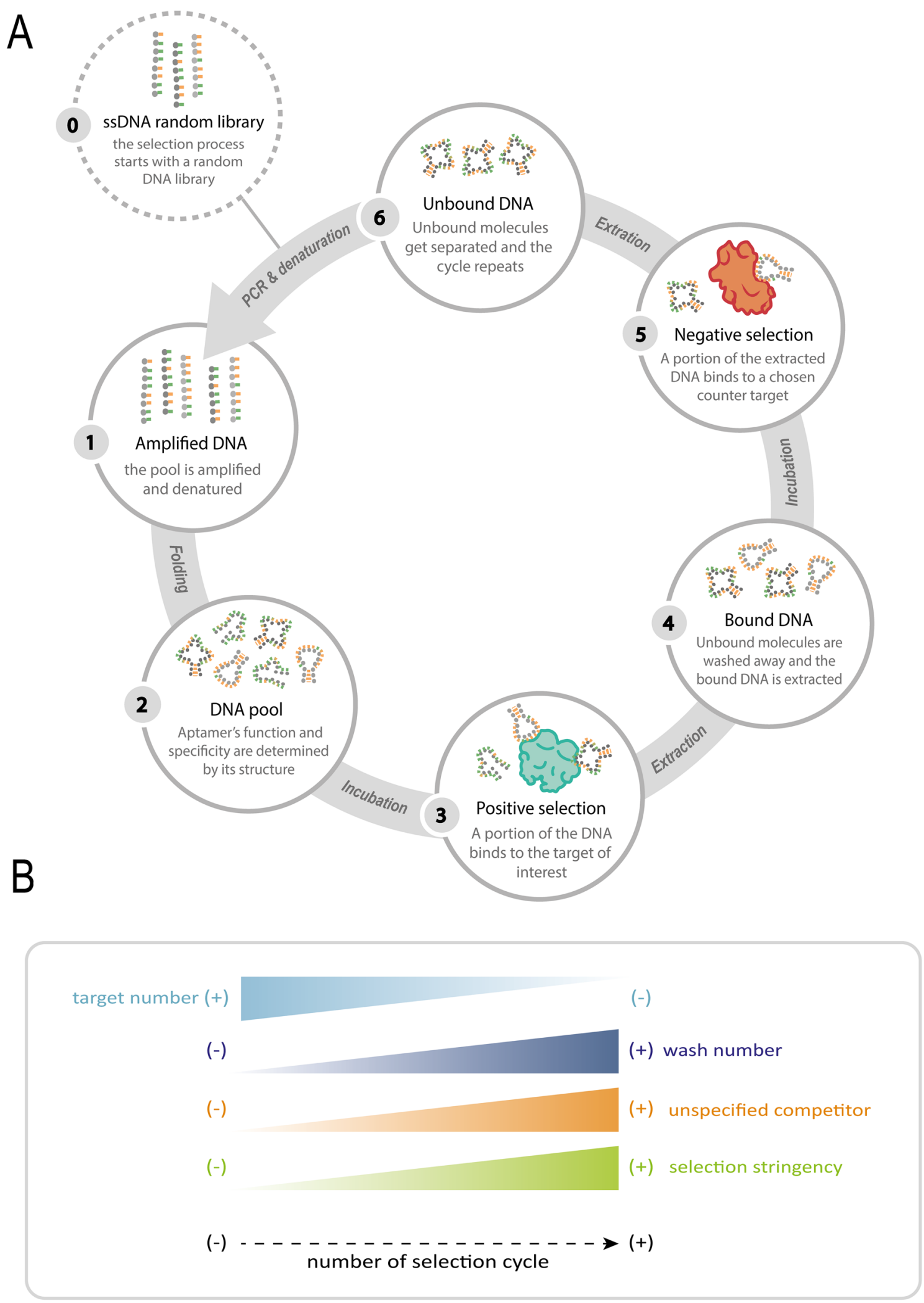

Figure 2: Schematic representation of the SELEX process. (A) Not only is the process iterative, but also (B) with each round, the stringency is increased, thus resulting in higher affinity and specificity. This increase is achieved by increasing both the number of washes and non-specific competitors, and decreasing the number of target molecules within every cycle. 
for in vivo and in vitro imaging, diagnosis, and targeted drug delivery (Table 1).

In order to ensure that the findings of basic and translational research have an impact on clinical practice, it is not enough to select an aptamer or pool of aptamers against a tumor cell type. One must anticipate the desired applications for the resulting molecular probes, as this will be determinant for the definition of selection conditions, such as temperature of incubation with the target and/or the most appropriate counter targets. For instance, if the intent is to develop a diagnostic test that can identify circulating tumor cells, the aptamer should be able to differentiate a tumor cell from healthy blood cells. If an aptamer is to be used as a tumor cell marker on a fixed tissue sample, it should not bind to healthy tissue. Moreover, problems arising from the selection conditions may interfere with process efficiency, such as contamination with dead cells in the positive selection cycle, which leads, to some degree, to the selection of aptamers against dead cells as opposed to the intended target [55]. Furthermore, the use of aptamers selected against live cells with fixed cells can lead to false positive results.

Some studies have successfully shown the use of aptamers for in vivo and in vitro imaging of tumor cells. Shi et al. [66], have shown, for the first time, the use of aptamer as a fluorescent probe for the identification of tumor cells (Ramos B-cell lymphoma) in living mice, proving the specificity, sensitivity and stability of aptamers for this purpose. More recently, the use of aptamers in the identification of pancreatic ductal adenocarcinoma tumor cells has been demonstrated by in vivo imaging and in fixed clinical specimens [47].

The identification of new biomarkers and, consequently, the development of specific aptamerbased biosensors, called aptasensors, which coupled with other techniques such as image or flow cytometry, microscopy and chromatography allow the detection and determination of the concentration of its target in the sample [24, 38, 85, 86]. Daniels and coworkers used cell-SELEX to select an aptamer - GBI10 -, which was shown to be a ligand for tenascin-C protein. It is interesting to note that, in this study, cell-SELEX cycles were performed at $4{ }^{\circ} \mathrm{C}$, to avoid receptor-mediated internalization [46]. However, if the aptamer does not bind well to its target at physiological temperature, it cannot be used in vivo. In view of that, the authors of the former cited work themselves suggested, for in vivo use, it would be necessary to develop a novel nucleaseresistant aptamer that binds the target with high affinity at $37^{\circ} \mathrm{C}$. Similarly, Champanhac et al. performing selection cycles at $4^{\circ} \mathrm{C}$, obtained aptamers with good affinity and specificity for their target, but some of these did not bind efficiently at $37^{\circ} \mathrm{C}$. In addition, internalization of the aptamer was evaluated. For this, aptamers were incubated with the target at $4^{\circ} \mathrm{C}$ for 30 minutes, followed by incubation at $37^{\circ} \mathrm{C}$ for another $90 \mathrm{~min}$. The internalization of aptamers by cells was assessed by treatment with trypsin leading to the exclusion of aptamers bound to the cell surface [48]. The authors suggested that these aptamers could be conjugated with drugs. However, it must be taken into account that the experimental design, which requires prior incubation at $4^{\circ} \mathrm{C}$, does not reflect a proof of concept regarding the use of this approach in cancer therapy. It is noteworthy that low temperatures inhibit internalization of aptamers. Certainly, the ability of aptamers to be internalized by target cells makes them a promise for the development of therapies based on aptamers for intracellular drug delivery [87].

In addition to acting as a specific ligand, aptamers may also be used in the development of new drugs, as they can act preventing the activity of their target, for example, inhibiting a membrane receptor [88]. Selection of aptamers that may act specifically on tumor cells and may regulate the activity of molecules involved in key processes for tumor progression, such as proliferation, adhesion, migration and immune response is one of the greater goals in oncology-related aptamer research. Furthermore, it is important to determine the action of these aptamers inside and outside the cell, the toxicity in healthy and tumor cells, the existence of possible side effects and the half-life inside the organism.

\section{APTAMERS AS CHEMOTHERAPY AGENTS}

Despite the most recent advances, cancer treatments, such as chemotherapy and radiotherapy, still have significant limitations regarding side effects, the major one being, of course, damage to healthy cells. Consequently, cancer treatments with minimal drug and radiation doses have been in the spotlight [89] due to the fact that they (attempt to) target, specifically, non-healthy cells. Some cell receptors expressed in normal cells are overexpressed in cancer cells; thus, efficiency could be enhanced whilst minimizing the damage to normal cells [90].

To improve the effectiveness of chemotherapy, some drugs have been conjugated with small molecules to decrease the resistance of cancer cells, such as Doxorubicin (DOX) - a drug used in many cancer treatments [91]. DOX is a drug approved by Food and Drug Administration (FDA) that acts as a genomic DNA intercalator, preventing DNA replication and is a member of the anthracycline family that may present some side effects, such as irreversible cardiomyopathy due to oxidative stress, downregulation of genes for contractile proteins, apoptosis and partial loss of myocardial fibers [92-95]. Subsequently, aptamer-based therapies are being studied in order to reduce such side effects. AS1411 is an antiproliferative DNA aptamer with a G-quadruplex structure developed to target nucleolin - a protein that is found in high levels in cancer cells. This oligonucleotide was the first aptamer that showed potential for clinical 
Table 1: Aptamers selected using the cell-SELEX procedure

\begin{tabular}{|c|c|c|c|c|c|c|}
\hline Aptamer & Cancer types & Target & $\begin{array}{l}\text { Subtractive } \\
\text { selection }\end{array}$ & $\begin{array}{l}\text { Cycles of } \\
\text { selection }\end{array}$ & $\begin{array}{l}\text { Suggested function/ } \\
\text { application }\end{array}$ & Reference \\
\hline GBI-10 & Glioblastoma & U251 cells line & - & 21 & Identification of targets & $\begin{array}{l}\text { Daniels et al., } \\
2003 \text { [46] }\end{array}$ \\
\hline- & $\begin{array}{l}\text { Glioblastoma } \\
\text { Multiforme }\end{array}$ & A-172 cell line & - & 18 & $\begin{array}{c}\text { Diagnosis, targeted } \\
\text { drug delivery, and } \\
\text { discovery of molecular } \\
\text { marker }\end{array}$ & $\begin{array}{c}\text { Bayrac et al., } 2011 \\
{[56]}\end{array}$ \\
\hline $\begin{array}{l}\text { GBM128 } \\
\text { and } \\
\text { GBM131 }\end{array}$ & Glioblastoma & $\begin{array}{l}\text { U118-MG cell } \\
\text { line }\end{array}$ & SVGp12 cells & 30 & $\begin{array}{l}\text { Identification } \\
\text { of glioblastoma } \\
\text { biomarkers }\end{array}$ & $\begin{array}{c}\text { Kang et al., } 2012 \\
\text { [57] }\end{array}$ \\
\hline- & Glioblastoma & $\begin{array}{l}\text { Tumor-initiating } \\
\text { Cells }\left(\mathrm{CD} 133^{+}\right)\end{array}$ & $\begin{array}{l}\text { Non-stem glioma } \\
\text { cells and neural } \\
\text { progenitors cells }\end{array}$ & 8 & $\begin{array}{l}\text { Aptamer-based } \\
\text { therapies combined } \\
\text { with conventional or } \\
\text { targeted therapies }\end{array}$ & $\begin{array}{c}\text { Kim et al., } 2013 \\
{[58]}\end{array}$ \\
\hline $\begin{array}{l}\mathrm{U} 2, \mathrm{U} 8, \\
\mathrm{U} 19 \text {, and } \\
\mathrm{U} 31\end{array}$ & Glioblastoma & $\begin{array}{c}\text { U87 } \\
\text { overexpressing } \\
\text { EGFRvIII }\end{array}$ & U87MG cell line & 11 & $\begin{array}{l}\text { Molecular imaging } \\
\text { probe }\end{array}$ & $\begin{array}{l}\text { Wu et al., } 2014 \\
{[59]}\end{array}$ \\
\hline \multirow[t]{2}{*}{ WQY-9-B } & Gliosarcoma & K308 & SVGp12 & 16 & $\begin{array}{l}\text { Molecular probe for } \\
\text { diagnosis }\end{array}$ & $\begin{array}{c}\text { Wu et al., } 2016 \\
{[60]}\end{array}$ \\
\hline & Glioma & $\begin{array}{l}\text { U87MG glioma } \\
\text { cells }\end{array}$ & T98G cells & 14 & $\begin{array}{l}\text { Discovery of new } \\
\text { molecular targets }\end{array}$ & $\begin{array}{l}\text { Cerchia et al., } \\
2009[61]\end{array}$ \\
\hline KMF2-1a & Breast cancer & MCF-10AT1 & MCF-10A1 & & $\begin{array}{l}\text { Cell type-specific } \\
\text { intracellular delivery }\end{array}$ & $\begin{array}{c}\text { Zhang et al., } 2012 \\
{[62]}\end{array}$ \\
\hline MS03 & Breast cancer & MCF-7 cells & $\begin{array}{l}\text { MCF-10A and } \\
\text { MCF-7sal cells }\end{array}$ & 13 & $\begin{array}{l}\text { Diagnostic and } \\
\text { therapeutic applications }\end{array}$ & $\begin{array}{l}\text { Lu et al., } 2015 \\
{[63]}\end{array}$ \\
\hline - & Breast cancer & TUBO cell line & CT26 cell line & 12 & $\begin{array}{c}\text { Targeted breast cancer } \\
\text { therapy }\end{array}$ & $\begin{array}{l}\text { Moosavian et al., } \\
2015 \text { [64] }\end{array}$ \\
\hline KW16-13 & $\begin{array}{l}\text { Breast ductal } \\
\text { carcinoma }\end{array}$ & MCF10CA1h & MCF10A & 18 & $\begin{array}{l}\text { Development as novel } \\
\text { anti-tumor therapeutics }\end{array}$ & $\begin{array}{l}\text { Chandrasekaran } \\
\text { et al., } 2016 \text { [65] }\end{array}$ \\
\hline TD05 & B-cell lymphoma & Ramos cells & - & 23 & $\begin{array}{l}\text { In vivo fluorescence } \\
\text { imaging }\end{array}$ & $\begin{array}{l}\text { Tang et al., } 2007 \\
\text { [51]; Shi et al., } \\
2010[66]\end{array}$ \\
\hline $\begin{array}{l}\text { S3, S5, } \\
\text { S12, and } \\
\text { S27 }\end{array}$ & $\begin{array}{l}\text { Nasopharyngeal } \\
\text { carcinoma }\end{array}$ & $\begin{array}{l}\text { NPC 5-8F cell } \\
\text { line }\end{array}$ & NP69 cell line & 22 & $\begin{array}{c}\text { Identification of } \\
\text { biomarkers for early } \\
\text { diagnosis and targeted } \\
\text { therapy }\end{array}$ & $\begin{array}{c}\text { Jia et al., } 2016 \\
{[67]}\end{array}$ \\
\hline \multirow[t]{2}{*}{-} & Lung cancer & $\begin{array}{l}\text { NCI-H69 SCLC } \\
\text { cell line }\end{array}$ & $\begin{array}{l}\text { NCIH661 NSCLC } \\
\text { cell line }\end{array}$ & 25 & $\begin{array}{l}\text { Lung cancer subtyping } \\
\text { during screening and } \\
\text { appropriate treatment } \\
\text { planning }\end{array}$ & $\begin{array}{c}\text { Chen et al., } 2008 \\
{[68]}\end{array}$ \\
\hline & $\begin{array}{l}\text { Small cell lung } \\
\text { cancer }\end{array}$ & SBC3 & RERF-LC-MA & 16 & $\begin{array}{l}\text { Specific detection } \\
\text { probes }\end{array}$ & $\begin{array}{c}\text { Kunii et al., } 2011 \\
{[69]}\end{array}$ \\
\hline $\begin{array}{l}\text { TLS1, } \\
\text { TLS3, } \\
\text { TLS4, } \\
\text { TLS6, } \\
\text { TLS7, } \\
\text { TLS9, and } \\
\text { TLS11 }\end{array}$ & Liver cancers & $\begin{array}{l}\text { BNL 1ME A.7R.1 } \\
\text { cell line }\end{array}$ & BNL CL. 2 cell line & 16 & $\begin{array}{l}\text { Development of } \\
\text { molecular probe }\end{array}$ & $\begin{array}{c}\text { Shangguan et al., } \\
2008[70]\end{array}$ \\
\hline
\end{tabular}

(Continued) 


\begin{tabular}{|c|c|c|c|c|c|c|}
\hline Aptamer & Cancer types & Target & $\begin{array}{l}\text { Subtractive } \\
\text { selection }\end{array}$ & $\begin{array}{l}\text { Cycles of } \\
\text { selection }\end{array}$ & $\begin{array}{l}\text { Suggested function/ } \\
\text { application }\end{array}$ & Reference \\
\hline & Liver cancer & HepG2 & THLE-2 & 19 & $\begin{array}{l}\text { Targeted therapies, and } \\
\text { imaging probe }\end{array}$ & $\begin{array}{c}\text { Xu et al., } 2015 \\
{[50]}\end{array}$ \\
\hline- & Hepatocarcinoma & HepG2 cells & $\begin{array}{l}\text { Primary normal } \\
\text { human liver } \\
\text { hepatocyte cells, }\end{array}$ & 11 & $\begin{array}{l}\text { Selective delivery of } \\
\text { anticancer drugs }\end{array}$ & $\begin{array}{l}\text { Ninomiya et al., } \\
2013 \text { [71] }\end{array}$ \\
\hline $\begin{array}{l}\text { LY- } 1,13, \\
46,32, \\
27 / 45, \text { and } \\
7 / 43\end{array}$ & $\begin{array}{l}\text { Hepatocellular } \\
\text { carcinoma }\end{array}$ & $\begin{array}{l}\text { HCCLM9 cell } \\
\text { line }\end{array}$ & MHCC97L cell line & 10 & $\begin{array}{l}\text { Identification of new } \\
\text { diagnostic targets } \\
\text { and developing new } \\
\text { targeted therapeutics }\end{array}$ & $\begin{array}{l}\text { Wang et al., } 2013 \\
\text { [72]; Chen et al., } \\
2016 \text { [39] }\end{array}$ \\
\hline LY-1 & Liver cancers & HCCLM9 & MHCC97L & 9 & $\begin{array}{l}\text { Development of } \\
\text { molecular probe } \\
\text { and chemotherapy } \\
\text { for metastatic } \\
\text { hepatocellular } \\
\text { carcinoma }\end{array}$ & $\begin{array}{c}\text { Rong et al., } 2016 \\
{[73]}\end{array}$ \\
\hline- & Cholangiocarcinoma & QBC-939 cells & SMMC-7721 & 13 & $\begin{array}{l}\text { Early diagnosis and } \\
\text { therapeutics }\end{array}$ & $\begin{array}{c}\text { Wan et al., } 2015 \\
{[74]}\end{array}$ \\
\hline- & Gastric carcinoma & AGS cell line & GES- 1 cell line & 12 & $\begin{array}{l}\text { Identify biomarkers for } \\
\text { gastric cancer diagnosis } \\
\text { and targeting therapy. }\end{array}$ & $\begin{array}{c}\text { Cao et al., } 2014 \\
{[75]}\end{array}$ \\
\hline PL1-8 & $\begin{array}{l}\text { Pancreatic ductal } \\
\text { adenocarcinoma }\end{array}$ & PL45 cell line & TOV-21G cell line & 23 & $\begin{array}{c}\text { Biomarkers } \\
\text { identification and drug } \\
\text { delivery }\end{array}$ & $\begin{array}{c}\text { Champanhac et al., } \\
2015 \text { [48] }\end{array}$ \\
\hline XQ-2d & $\begin{array}{l}\text { Pancreatic ductal } \\
\text { adenocarcinoma }\end{array}$ & PL45 cell line & $\begin{array}{l}\text { hTERT-HPNE cell } \\
\text { line }\end{array}$ & 15 & $\begin{array}{l}\text { In vivo imaging } \\
\text { and clinical tissue } \\
\text { recognition }\end{array}$ & $\begin{array}{c}\text { Wu et al., } 2015 \\
{[47]}\end{array}$ \\
\hline \multirow[t]{2}{*}{$\begin{array}{l}\text { Aptamers } \\
1 \text { and } 146\end{array}$} & Pancreatic cancer & HPAC cell line & HPDE cell line & 16 & $\begin{array}{l}\text { CSCs targeting drug } \\
\text { delivery, or circulating } \\
\text { tumor cell detection }\end{array}$ & $\begin{array}{c}\text { Kim et al., } 2017 \\
\text { [49] }\end{array}$ \\
\hline & Ovarian cancer & TOV-21G & $\mathrm{HeLa}$ & 22 & $\begin{array}{l}\text { Identification of } \\
\text { biomarkers }\end{array}$ & $\begin{array}{c}\text { Van Simaeys et al., } \\
2010 \text { [76] }\end{array}$ \\
\hline $\begin{array}{l}\text { RLA01, } \\
\text { RLA02, } \\
\text { and } \\
\text { RLA03 }\end{array}$ & Ovarian cancer & Caov-3 cell & HOSE 6-3 cells & 15 & $\begin{array}{c}\text { Diagnostic and drug } \\
\text { delivery }\end{array}$ & $\begin{array}{l}\text { Benedetto et al., } \\
2015 \text { [77] }\end{array}$ \\
\hline- & Colorectal Cancer & $\begin{array}{l}\text { DLD-1, Dukes' } \\
\text { type C colorectal } \\
\text { adenocarcinoma }\end{array}$ & HCT 116 & 16 & $\begin{array}{l}\text { Identify specific } \\
\text { biomarkers }\end{array}$ & $\begin{array}{c}\text { Sefah et al., } 2010 \\
{[78]}\end{array}$ \\
\hline- & $\begin{array}{c}\text { Metastatic colorectal } \\
\text { cancer }\end{array}$ & LoVo cells & HCT- 8 cells & 22 & $\begin{array}{l}\text { Multi-target cell } \\
\text { imaging/ multi-target } \\
\text { drug therapy }\end{array}$ & Li et al., 2014 [79] \\
\hline- & Colorectal cancer & $\begin{array}{c}\text { CR-CSC x HCT-8 } \\
\text { CRC line }\end{array}$ & $\begin{array}{l}\text { HCT-8 CRC line } \mathrm{x} \\
\text { CR-CSC }\end{array}$ & 5 & $\begin{array}{l}\text { Colorectal cancer cells } \\
\text { and stem cells }\end{array}$ & $\begin{array}{c}\text { Hung et al., } 2015 \\
\text { [43] }\end{array}$ \\
\hline XL-33-1 & Colon cancer & SW620 cells & SW480 cells & 14 & $\begin{array}{c}\text { Metastatic cancer } \\
\text { diagnosis and treatment }\end{array}$ & Li et al., 2015 [80] \\
\hline- & Prostate cancer & PC3 & $\begin{array}{l}\text { HeLa and SMMC- } \\
7721 \text { cells }\end{array}$ & 17 & $\begin{array}{l}\text { Diagnosis and target } \\
\text { therapy }\end{array}$ & $\begin{array}{c}\text { Wang et al., } 2014 \\
{[81]}\end{array}$ \\
\hline- & $\begin{array}{c}\text { Prostate } \\
\text { adenocarcinoma }\end{array}$ & LNCaP cells & PC-3 cell line & 10 & $\begin{array}{c}\text { Diagnostic and targeted } \\
\text { drug delivery }\end{array}$ & $\begin{array}{c}\text { Almasi et al., } 2016 \\
\text { [82] }\end{array}$ \\
\hline
\end{tabular}




\begin{tabular}{|c|c|c|c|c|c|c|}
\hline Aptamer & Cancer types & Target & $\begin{array}{l}\text { Subtractive } \\
\text { selection }\end{array}$ & $\begin{array}{l}\text { Cycles of } \\
\text { selection }\end{array}$ & $\begin{array}{l}\text { Suggested function/ } \\
\text { application }\end{array}$ & Reference \\
\hline- & Prostate cancer & PC-3 cell line & RWPE-1 & 9 & $\begin{array}{l}\text { Identification of } \\
\text { biomarker }\end{array}$ & $\begin{array}{c}\text { Souza et al., } 2016 \\
{[83]}\end{array}$ \\
\hline- & Osteosarcoma & U-2 OS cell line & $\begin{array}{l}\text { SGC7901, MCF-7 } \\
\text { and HT-1080 }\end{array}$ & 13 & $\begin{array}{l}\text { Specific diagnosis and } \\
\text { developing probe- } \\
\text { carrier-antitumor drug } \\
\text { complexes and targeted } \\
\text { therapies }\end{array}$ & $\begin{array}{c}\text { Wang et al., } 2015 \\
\text { [84] }\end{array}$ \\
\hline
\end{tabular}

Over the past few years, the number of cancer-related aptamers selected using cell-SELEX has increased significantly. Their applications are, clearly, diverse - from in vivo imaging to drug delivery, all the way to identification of new diagnostic targets.

trial development in several cancer treatments and has been used in other studies to enhance the treatment efficiency against cancer cells $[96,97]$. Li et al. developed an AS1411 aptamer system that releases DOX into human breast adenocarcinoma cells (MCF-7 cells). There was no evidence of drug accumulation in the heart of MCF7 tumor-bearing mice. Binding of AS1411 to MCF-7 receptors was significantly increased when the micelle system was used. This led to the decrease of DOX accumulation in cardiac cells, thus reducing cardiac tissue damage and necrosis, providing a promising strategy for aptamer based therapy [98]. Moreover, AS1411 reduced multi-drug resistance produced by glycoprotein-P (P-gP) efflux and showed antitumor activity and low levels of cardiotoxicity caused by DOX in MCF-7/ADR tumorbearing mice [99]. This very same study used a bubblegenerating agent that creates permeable defects in the bilipid layers when the microenvironment heats up to $42^{\circ} \mathrm{C}$, which led to an increase of intracellular DOX concentration - a potentially harmful drug-releasing procedure. This limitation in therapeutic use of DOX could be overcome through the use of new aptamers binding to and inhibiting proteins necessary for $\mathrm{P}-\mathrm{gP}$ production, leading to increased release of DOX and reduced viability of cancer cells without any cardiomyopathy side effects. Trinh et al. also used AS1411 and DOX in a hepatocellular carcinoma human model (HCC), showing no cardiac nor endocrine side effects, as well as no weight loss [100].

Atabi et al. showed aptamers that enhanced the storage of DOX in LNCaP cells (human prostate carcinoma cell line); Jing et al. constructed a double aptamer system that reduces human prostate cancer cell growth (LNCaP and PC3); Jeong et al. used mucin-1 aptamer (MUC-1) and DOX as treatment tools, on MCF-7 breast cancer cells and Sun et al. showed that the SL2B aptamer inhibits tumor growth in HT-29 cells (a human colorectal adenocarcinoma cell line) [101-104]. All these studies paved the way for the development for aptamers that can lead to lower-dosage chemotherapy, thus decreasing the aforementioned side effects. Aptamers binding to proteins or receptors involved in signaling pathways that lead to apoptosis and/or interfere with angiogenesis pathways are good examples of what could be done to improve such protocols. Another good example would be the use of an aptamer that inhibits topoisomerase II in order to reduce tumor cell proliferation.

Other types of drugs have been used in chemotherapy studies, some of which have been tested in conjugation with aptamers. Docetaxel (DTX) is an anticancer drug from the taxane family that causes tubulin depolymerization and microtubule aggregation, promoting cell death. However, it can cause intravenous toxicity in malignant brain tumors [105]. Gao et al. used AS1411 as an enhancer of the anti-glioma effect of DTX in C6 glioma cell line [106]. Glioma treatment is particularly difficult, due to the fact that both the blood-brain barrier (BBB) and the brain-glioma barrier reduce drug release from the blood into tumor cells. These types of studies can be improved with double aptamer systems - one for BBB recognition and another for tumor recognition.

Paclitaxel (PTX) is a neoplastic agent that acts as chemotherapeutic agent in malignant glioma cells [107], however, its lower aqueous solubility may affect its effectiveness. Aptamers could be selected to enhance the solubility of PTX to support the enhanced permeability and retention (EPR) effect of solid tumors. This application can increase tumor permeation and retention of macromolecular drugs to reduce toxicity to normal cells.

Taghavi et al. worked with anti-MUC-1 aptamer (5TR1) and enhanced Epirubicin (Epi) drug released into MCF-7 breast cancer cells and CHO cells (hamster ovary cell line) [108]. Epi is a drug of the anthraclycine family that can cause cardiotoxicity by accumulative doses. New aptamers could enhance recognition of MUC-1 glycoprotein to reduce cytotoxicity of myocardium cells improving Epi release to increase DNA intercalation, inhibit topoisomerase II and increasing cancer cell damage.

Ray et al. used an RNA aptamer to improve the effectiveness of Gemcitabine (Gem) drug chemotherapy targeting pancreatic tumor cells, which overexpress EGFR. This aptamer recognizes EGFR in pancreatic cancer cells and internalizes itself, along with Gem coupled to a polymer, resulting in inhibition of tumor 
cell proliferation with low toxicity levels [109]. Gem is known as a nucleoside molecule that can produce side effects in high concentration due the toxicity of normal cells, leading to neutropenia disease (low neutrophil concentration). To overcome limitations of this toxicity effect, aptamers that influence Gem phosphorylation status upon internalization could be used. Gem is a nucleoside that can be phosphorylated intracellularly to allow inhibition of ribonucleotide reductase activity and subsequently preventing DNA elongation of proliferating cancer cells.

These studies show that there is much uncovered ground for aptamer-based chemotherapy. Whether by improving drug effectiveness or to reducing side effects (or both), aptamers can definitely improve cancer therapy.

\section{APTAMERS AS BIOTHERAPY AGENTS}

\section{Aptamers and immunotherapy}

Recent advances in cancer therapy have brought back to prominence the importance of the immune system in the tumor control. In fact, a major recent milestone in cancer immunotherapy has come with the unprecedented results obtained in clinical trials of advanced cancer patients treated with immune-checkpoint blockade antibodies. With such results, one cannot avoid wondering if the success of fighting cancer lies not only in the relationship between the drug and its target, but in an alliance between the drug and the human body. Here the drug may pave the way, and the body itself delivers the definitive blow. Combining different aptamer functionalities with other molecules of interest, such as reporter groups or proteins, provides a wide range of applications for aptamers as biotherapy tools. Aptamers have been regarded as rivals for "antibody rivals" for a long time however, given the most recent findings, it makes sense to think that, maybe, both tools could work together. This is especially important when it comes to fighting cancer.

Zhao et al. developed a bivalent RNA aptamer, which inhibits the interaction of heat shock factor HSF1 with its cognate DNA promoter elements, thus downregulating HSF1 expression and, therefore, sensitizing tumor cells to anti-cancer drugs [110]. In a different study, Lozano et al. developed an aptamer against Foxp3 by a CD28 2'-fluoro RNA aptamer [111]. The group has shown, as a proof of concept, that the P60 Foxp3 inhibitor peptide can be conjugated with a CD28 targeting aptamer for delivering the peptide to CD28expressing cells, thus inhibiting T regulatory cells when they are hijacked by the tumor micro-environment to evade the immune response. Both works are very good examples of how regulatory proteins can be prevented from being an obstacle in therapy. Anticancer antibodies have certain limitations when it comes to therapeutic applications, due to the ability of cancer cells to block immune responses. CD46 (membrane cofactor protein, MCP), CD55 (decay-accelerating factor, DAF)) and CD35 (complement receptor type-1, CR1) are well known for interfering with the aforementioned therapeutic agents. They protect normal tissues from accidental injury by activated complement and confer resistance to cancer cells, thus limiting the effect of complement-fixing monoclonal antibodies. Designing aptamers that inhibit their cancer cell-protecting action would allow anticancer antibodies (or another aptamer) action. John Gordon Bruno has reported the use of two distinct DNA aptamers, developed by Ferreira et al., against MUC1 antigen [112]. In this study, aptamers were successful in enabling the death of MCF-7 cells when linked to the first component of complement (C1q) via a biotin-streptavidin system, resulting in the death of $50 \%$ of treated cells. Possible reasons for such effect include antigenic shedding in vitro and membrane-bound complement regulatory proteins (mCRPs) on the cell surface. CD46, CD55 and CD59 are good examples of such mCRPs. This is, yet, another case of a possible aptamer-immune system team-up for treating oncological diseases.

Immunotherapy is an effective and promising novel treatment strategy against several types of cancer, such as melanoma, non-small cell lung cancer, head cancer and neck cancer. Cytotoxic T lymphocyte protein-4 (CTLA-4) and programmed cell death protein-1 (PD-1) are critical immune checkpoint molecules that negatively regulate $\mathrm{T}$ cell activation, thus allowing tumors to evade the adaptive immune response. The use of immune checkpoint blockadetargeted antibodies has already shown clinical efficacy, which has led to their FDA approval in the treatment of several solid tumors [54, 113-115]. However, to this day, the medical community still lacks an accurate biomarker that allows appropriate patient selection $[3,116]$. Aptamers could be used to identify such biomarkers and/or their variations in different cancer types. It is also important to note that treatment with such immunostimulatory therapies is not completely devoid of side effects, since cases of heart failure due to acute myocarditis have been reported $[117,118]$. One of these particular studies, conducted by Läubli et al. revealed a correlation between the use of such drugs and impaired ventricular function [117]. Histological analysis of a myocardial biopsy revealed not only lymphocytic infiltration with a predominance of CD8-positive cells and a reduction of FOXP3-positive regulatory $\mathrm{T}$ cells. Although symptomatic treatment is the only form of therapy for most forms of myocarditis [119], this particular scenario could benefit from the use of aptamers against these targets, since they could be used as biomarkers for the aforementioned elements and allow for an early diagnostic of this side-effect. The synergy between PD-1 and CTLA-4 has been proven to be very effective, and it is likely that this approach will continue to be used in the near future; however, while appealing, 
the double checkpoint inhibition strategy has a significant toxicity rate [114]. Aptamers could also play a significant role when planning combination therapies, in a sense that they could help identifying biomarkers involved in such adverse reactions. Malignant pleural mesothelioma (MPM), for instance, is a drug-resistant tumor in the mesothelial surfaces of the lung pleura, whose biomarkers lack specificity and sensitivity [120]. The development of accurate biomarkers for this disease could improve the treatment success rate significantly. CD44 is one of the most well-known MPM markers; however, it lacks an accurate measurement tool. Developing aptamers against this marker could help diagnosing this ailment sooner, which, in turn, would allow for a more planned course of treatment.

More recently, some groups have been turning their attention to another set of biomarkers, such as metabolic biomarkers. This set of markers is the most stable of all end-products among the four functional levels (genome, transcriptome, proteome and metabolome) related to cell function. Colo-rectal cancer (CRC) therapies have been taking advantage of this approach. Accumulation of lactate, phenylalanine, tyrosine, glutamine, proline, threonine, glutamic acid and arginine have, among a few others, have been identified as important CRC biomarkers [121-124]. Aptamers can be used to discover novel metabolic biomarkers, including the above-mentioned ones and especially those that are secreted by the cells. Using aptamers to quantify such metabolites can also prove to be advantageous for the study of cancer progression, since these metabolites can help understand the behavior of tumor cells and how they respond (if at all) to conventional therapies.

Ultimately, one day, it will be possible to predict which patients will benefit the most from a particular treatment, thus sparing them expensive and, sometimes, painful futile treatments. This idea has led research groups to study potential predictive biomarkers for personalized medicine, which span from gene expression signatures [125] to T-cell expression patterns within the tumor microenvironments. This approach would also benefit greatly from the aptamer technology, in a sense that aptamers could be used to analyze the presence of biomarkers, as well as variations in their concentrations, thus helping to design the best possible treatment.

\section{Aptamers as anticancer drug-delivery systems}

Drug-delivery systems have been around for a while now, and they have, indeed, broken ground in terms of therapeutic approaches. Nanocarriers (colloidal nanoscale systems capable of transporting anticancer agents), such as small molecular weight drugs or macromolecules, for instance, do not only allow for treatment in loco, but they also protect the drug from degradation, reduce renal clearance, increase its half-life and help controlling release kinetics. Sometimes, they also improve solubility [126, 127]. However, the number of nanocarriers currently undergoing clinical trials is very small [128]. This can be attributed to the fact that, in general and especially in rapidgrowth tumors, cancer cells are located adjacent to the endothelial barrier, and nanocarriers with targeting moieties will bind to the first receptors they find, ultimately failing to penetrate the rest of the tumor $[128,129]$. This particular scenario is perfect for Cell-SELEX. Aptamers selected through this process bind to cellular receptors and may help the aforementioned nanocarriers by saturating the receptors that prevent them from penetrating the rest of the tumor.

The use of RNA interference (RNAi), short interfering RNA (siRNA), targeting of micro RNAs (miRNAs) and antisense oligo (ASO) in cancer therapy for silencing gene expression has also been growing significantly [130]. However, even though most studies reveal that these tools are effective, their use is still filled with challenges that need to be overcome; mainly, the ones regarding their delivery, off-target effects and low concentrations in the target site. Aptamers can be used overcome these adversities. Receptor-mediated endocytosis, for instance, could account for concentrationrelated problems. Aptamers that target cellular uptakerelated cell-surface receptors could be used to enforce this approach (Figure 3). Lipid-based drug delivery systems could also benefit from their use, given that one of their main drawbacks is the lack of control regarding their accumulation in tumor cells [131]. Berezhnoy et al. selected an aptamer (4-1BB aptamer-siRNA chimera against mTOR (Raptor)) that acts like this. Expression of mTOR (mechanistic target of rapamycin) reduces the differentiation of effector cells into T-memory cells. The 4-1BB aptamer targets activated $\mathrm{T}$ cells delivering the Raptor siRNA into the cell cytoplasm upon the internalization of 4-1BB (CD137). The siRNA within the cell inhibits $\mathrm{mTOR}$ favoring the induction of memory $\mathrm{T}$ cells [132]. Another good example of aptamer-siRNA chimeras that affect gene expression, is the one proposed by Dassie et al. The group managed to select a siRNAbinding aptamer that promotes regression of PSMAexpressing tumors [133] (Figure 3). This interesting idea could be expanded to, for example, metalloproteinases (MMP) and/or kallikrein (klk) secreting tumors. That very same group has also reported the use of an aptamersiRNA chimera as a delivery agent. The group managed to select an RNA aptamer that delivers a cytotoxic siRNA to directly to prostate cancer cells for targeting prostate cancer-specific pro-survival genes, thus resulting in cell death [134, 135] (Figure 3). This was, in fact, the first study providing a proof-of-concept regarding the ability (and utility) that aptamers have to deliver functional RNAi to cells in vitro and in vivo.

In the aftermath of this revelation, other groups started to work in similar delivery systems. Liu et al. reported the use of an aptamer to deliver DOX 
Table 2: Clinical trials undertaken with aptamers targeting cancer

\begin{tabular}{lccc}
\hline Trial number & Cancer type & Study phase & Primary purpose \\
\hline NCT02957370 & Bladder & Observational & Discover biomarker \\
NCT03385148 & Colorectal & Phase 1 & Diagnostic \\
NCT01830244 & Breast & Phase 2 & Treatment $^{*}$ \\
NCT00056199 & Retinal & Phase 1 & Treatment \\
NCT01034410 & Acute myeloid leukemia & Phase 2 & Treatment \\
\hline
\end{tabular}

* The aptamer is not the focus of the study. Samples of patients who agree will be used to isolate cancer initiating cells generate breast cancer models and using aptamers to target tumors.

The number of known cancer-targeting aptamers in clinical trials corresponds to, approximately, $5 \%$ of the total number of aptamers known to be in that development stage. This content is of public domain (https://clinicaltrials.gov).
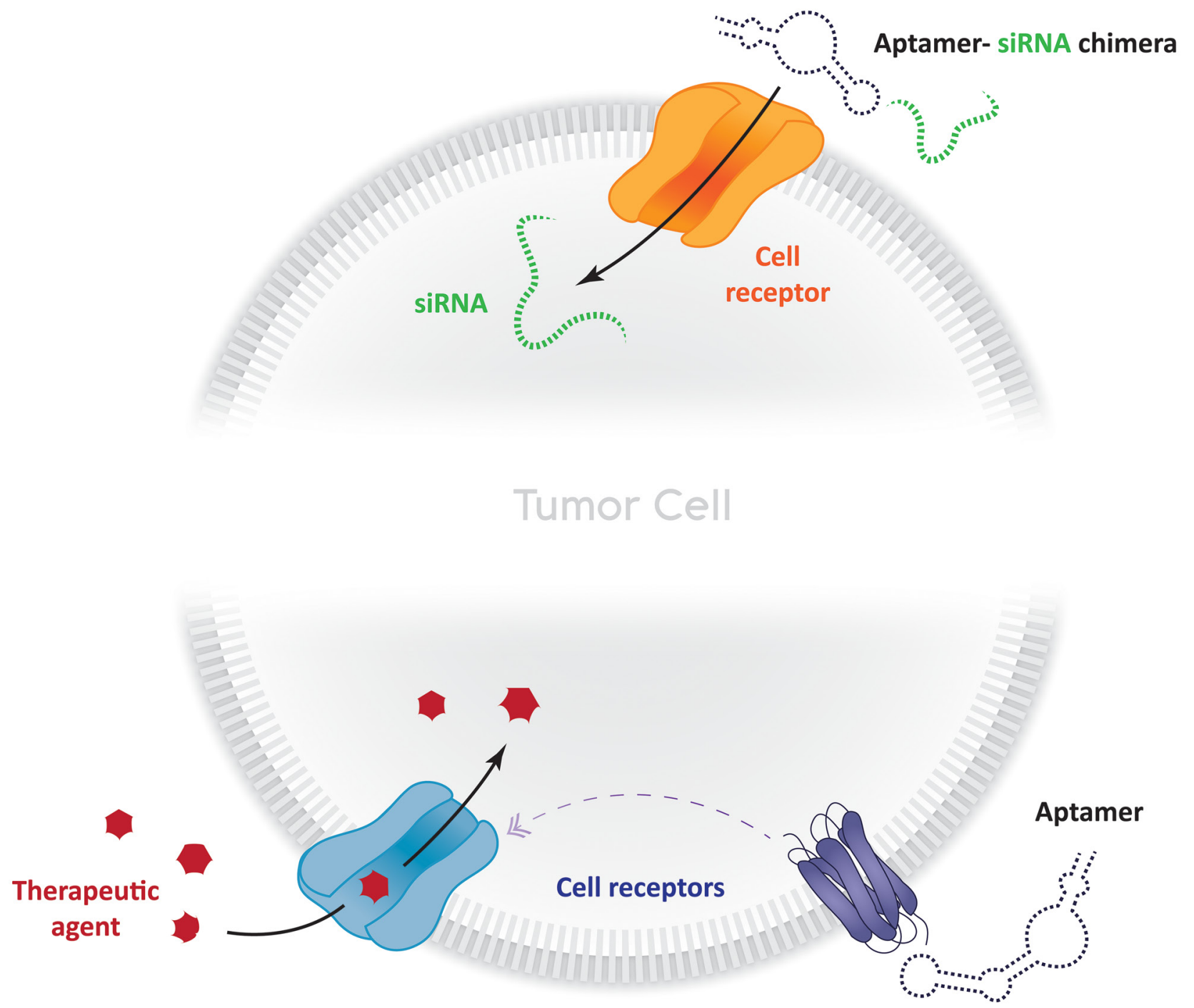

Figure 3: Strategies to enhance bio-therapeutic therapies in cancer using aptamers. Aptamer-siRNA chimeras can be used to stimulate receptor internalization, which leads to siRNA delivery within the cytoplasm. Aptamers can also be used to induce cellular uptake of therapeutic agents (drugs, other aptamers, nanoparticles, polymers) which can act in different ways by apoptosis induction, lower RNA expression, tumor regression, and other mechanisms. 
to HER2-positive breast cancer cells. The aptamerdoxorubicin complex (Apt-DOX) was obtained by intercalating Dox into the DNA structure of HB5 and managed to selectively deliver DOX to HER2-positive breast cancer cells while reducing the drug intake by HER2-negative cells in vitro with reduced cytotoxicity to HER2-negative cells [136]. In a somewhat similar fashion, Thiel et al. reported the use of RNA aptamers as delivery agents of chemo-sensitizing siRNAs to HER2-positive breast cancer cells. The group used a novel, cell-based selection approach for isolating RNA aptamers that have cell-internalizing capabilities while being cell-type specific [137]. These aptamers were covalently linked to siRNAs targeting the Bcl-2 gene (anti-apoptotic gene). When applied to cells, the HER2 aptamer-Bcl-2 siRNA conjugates selectively internalized into HER2-positive cells and silenced Bcl-2 gene expression, thus sensitizing them to chemotherapy with cisplatin. Both works show tremendous potential, since the specific characteristics of cancer cells are what makes this ailment so singular and the nuances of its treatment so intricate. In the light of the fact that both act on the same type of cell via recognition of expressed proteins, it would be interesting to see how these aptamers would interact when "stacked" -using one aptamer that acts as an apoptotic inducer by targeting anti-apoptotic genes along with another that delivers an apoptosis inducer might prove even more effective than using only one of them.

More recently, AlShamaileh et al. reported showed that EpCAM-aptamer-guided survivin RNAi effectively downregulated survivin expression both in colorectal cancer cells in vitro and in its mouse xenograft model for colorectal cancer. The group identified survivin as one of the key players responsible for the innate chemoresistance of colorectal cancer stem cells and their aptamer-guided survivin RNAi enhanced sensitivity towards 5-FU or oxaliplatin in colorectal cancer stem cells, increased apoptosis, inhibited tumor growth and improved the overall survival of mice bearing xenograft colorectal cancer [138].

Whether they carry siRNAs or other specific therapeutic tools, such as drugs, aptamers can be used as carriers in target-based therapies. Following this line of thought, Bahreyni et al. developed a nanocomplex made of graphene oxide and aptamers for treatment of cancer cells. The group designed two nano-complexes (MUC1 aptamer-NAS-24 aptamer-Graphene oxide and MUC1 aptamer-Cytochrome $\mathrm{C}$ aptamer-GO) that induce cell death in two cancer cell lines (MDA-MB-231 and MCF7) [139]. One of the aptamers (MUC1) acts as a probe promoting the internalization of the two nano-complexes. In turn, NAS-24 aptamer induces apoptosis via binding to vimentin expressed in cancer cells [37]. The cytochrome C targeting aptamer confirmed apoptosis induction promoted by the NAS-24 aptamer, since cytochrome $\mathrm{C}$ is known to have a significant role in the activation of caspase family which, in turn, triggers execution of programed cell death [140-142]. The complexity of this work reflects fairly well the infinite number of possibilities that aptamers (can) provide in terms of both therapeutic and diagnostic design in cancer biology.

\section{CLINICAL TRIALS}

Despite the increasing number of published studies demonstrating advances in the development of aptamers applied to oncological diseases, we have observed a very slow the progress in the utilization of this knowledge in clinical practice has been very slow. Particularly with regard to the use of aptamers in clinical trials, the public clinical trials database (http:// clinicaltrials.gov) lists around 33 clinical trials using aptamers for a wide range of therapeutic applications, of which only 5 are studies applied to oncology (Table 2).

As discussed throughout this review, aptamers have several applications in diagnosis, prognosis determination, adjuvant therapy and targeted therapy. Subsequently, several research groups have been engaged in the development of aptamers whose targets are relevant for oncology, including proteins such as EGFR, HER-2, VEGF, EpCAM and others [34, 143]. Furthermore many of these researches result in patents, as can be seen in the WIPO (World Intellectual Property Organization) which lists hundreds of published international patent applications in this field of knowledge. These data make us reflect on a possible deficit in translational research that facilitates the arrival of knowledge generated in basic research to the clinic in an agile and efficient way.

\section{CONCLUSIONS}

In the light of these examples, aptamers are definitely compounds of interest when it comes to cancer biology. Their applicability is rather vast, easy and has a low production cost. Also, considering how much ground there is to pave regarding cancer therapy and how versatile aptamers can be, their position as novelty tools is indisputable, whether as therapeutic and/or diagnostic tools or as complementary tools to already existing approaches.

\section{ACKNOWLEDGMENTS AND FUNDING}

H.U. acknowledges grant support from the Brazilian funding agencies Fundação de Amparo à Pesquisa do Estado de São Paulo (São Paulo Research Foundation, FAPESP Proj. Nr. 2012/50880-4) and Conselho Nacional de Desenvolvimento Científico e Tecnológico (CNPq) for fellowship support. R.L.P.'s and A.P.S.'s doctoral thesis research are supported by fellowships from Coordenação de Aperfeiçoamento de Pessoal de Nível Superior (CAPES). I.C.N. and I.O. thank FAPESP for post-doctoral FAPESP Proj. Nr., 2015/18730-0 and scientific initiation FAPESP Proj. Nr., 2017/00386-7. 


\section{CONFLICTS OF INTEREST}

There is no conflicts of interest whatsoever regarding this publication.

\section{REFERENCES}

1. Siegel R, Naishadham D, Jemal A. Cancer statistics, 2012. CA Cancer J Clin. 2012; 62: 10-29. https://doi.org/10.3322/ caac. 20138 .

2. Siegel R, Naishadham D, Jemal A. Cancer statistics, 2013. CA Cancer J Clin. 2013; 63: 11-30. https://doi.org/10.3322/ caac. 21166

3. Zugazagoitia J, Guedes C, Ponce S, Ferrer I, Molina-Pinelo $\mathrm{S}$, Paz-Ares L. Current challenges in cancer treatment. Clin Ther. 2016; 38: 1551-66. https://doi.org/10.1016/j. clinthera.2016.03.026.

4. Huang YF, Chang HT, Tan W. Cancer cell targeting using multiple aptamers conjugated on nanorods. Anal Chem. 2008; 80: 567-72. https://doi.org/10.1021/ac702322j.

5. Basil CF, Zhao Y, Zavaglia K, Jin P, Panelli MC, Voiculescu S, Mandruzzato S, Lee HM, Seliger B, Freedman RS, Taylor PR, Hu N, Zanovello P, et al. Common cancer biomarkers. Cancer Res. 2006; 66: 2953-61. https://doi. org/10.1158/0008-5472.CAN-05-3433.

6. Bast RC Jr, Lilja H, Urban N, Rimm DL, Fritsche H, Gray J, Veltri R, Klee G, Allen A, Kim N, Gutman S, Rubin MA, Hruszkewycz A. Translational crossroads for biomarkers. Clin Cancer Res. 2005; 11: 6103-08. https:// doi.org/10.1158/1078-0432.CCR-04-2213.

7. Stéhelin D. Oncogenes and cancer. Science. 1995; 267: 1408-09. https://doi.org/10.1126/science.7878455.

8. Roizen MF. Hallmarks of cancer: The next generation. Yearbook of Anesthesiology and Pain Management. 2012 2012-13. https://doi.org/10.1016/j.yane.2012.02.046.

9. Veenstra TD, Conrads TP, Hood BL, Avellino AM, Ellenbogen RG, Morrison RS. Biomarkers: Mining the biofluid proteome. Molecular \& Cellular Proteomics. 2005; 4: 409-18. https://doi.org/10.1074/mcp. M500006-MCP200.

10. Dholaria B, Hammond W, Shreders A, Lou Y. Emerging therapeutic agents for lung cancer. Journal of Hematology \& Oncology. 2016; 9: 138. https://doi.org/10.1186/ s13045-016-0365-z.

11. Kulbachinskiy AV. Methods for selection of aptamers to protein targets. Biochemistry (Moscow). 2007; 72: 1505 18. https://doi.org/10.1134/s000629790713007x.

12. Tuerk C, Gold L. Systematic evolution of ligands by exponential enrichment RNA ligands to bacteriophage $\mathrm{t} 4$ DNA polymerase. Science. 1990; 249: 505-10. https://doi. org/10.1126/science.2200121.

13. Gold L. Oligonucleotides as research, diagnostic, and therapeutic agents. J biol chem. 1995; 270: 13581-4 PMID: 7775406.
14. Ellington AD, Szostak J. in vitro selection of rna molecules that bind specific ligands. Nature. 1990; 346: 818-22. https://doi.org/10.1038/346818a0.

15. Dieckmann T, Suzuki E, Nakamura GK, Feigon J. Solution structure of an ATP-binding RNA aptamer reveals a novel fold. RNA. 1996; 2: 628-40.

16. Huizenga DE, Szostak JW. A DNA aptamer that binds adenosine and ATP. Biochemistry. 1995; 34: 656-65. https://doi.org/10.1021/bi00002a033.

17. Burke DH, Gold L. RNA aptamers to the adenosine moiety of s-adenosyl methionine: Structural inferences from variations on a theme and the reproducibility of selex. Nucleic Acids Research. 1997; 25: 2020-24. https://doi. org/10.1093/nar/25.10.2020.

18. Mercey R, Lantier I, Maurel MC, Grosclaude J, Lantier F, Marc D. Fast, reversible interaction of prion protein with rna aptamers containing specific sequence patterns. Archives of Virology. 2006; 151: 2197-14. https://doi. org/10.1007/s00705-006-0790-3.

19. Carasquilho KG, Ricker JÁ, Rigas IK, Miler JW, Gragoudas ES, Adamis AP. Controlled delivery of the anti-VEGF aptamer Eye001with poly(lactic-co-glycolic) acid microspheres. Invest Ophtalmol Vis Sci. 2003; 44: 290-299. https://doi.org/10.2174/138620706678249695.

20. Gold L, Janjic N, Jarvis T, Schneider D, Walker JJ, Wilcox SK, Zichi D. Aptamers and the rna world, past and present. Cold Spring Harbor Perspectives in Biology. 2012; 4: a003582. https://doi.org/10.1101/cshperspect.a003582.

21. Shamah SM, Healy JM, Cload ST. Complex target selex. Accounts of Chemical Research. 2008; 41: 130-38. https:// doi.org/10.1021/ar700142z.

22. Weiner GJ. Monoclonal antibody mechanisms of action in cancer. Immunologic Research. 2007; 39: 271-78. https:// doi.org/10.1007/s12026-007-0073-4.

23. Ulrich H, Martins AH, Pesquero JB. RNA and DNA aptamers in cytomics analysis. Cytometry A. 2004; 59: 220-31. https://doi.org/10.1002/cyto.a.20056.

24. Ulrich $\mathrm{H}$, Wrenger C. Disease-specific biomarker discovery by aptamers. Cytometry A. 2009; 75: 727-33. https://doi. org/10.1002/cyto.a.20766.

25. Wilson DS, Szostak JW. in vitro selection of functional nucleic acids. Annual Review of Biochemistry. 1999; 68: 611-47. https://doi.org/10.1146/annurev. biochem.68.1.611.

26. Famulok M., Mayer G, Blind M. Nucleic acid aptamers - from selection in vitro to applications in vivo. Accounts of Chemical Research. 2000; 33: 591-99. https://doi. org/10995196.

27. Rimmele M. Nucleic acid aptamers as tools and drugs: Recent developments. Chembiochem. 2003; 4: 963-71. https://doi.org/10.1002/cbic.200300648.

28. Lee JF, Stovall GM, Ellington AD. Aptamer therapeutics advance. Current Opinion in Chemical Biology. 2006; 10: 282-89. https://doi.org/10.1016/j.cbpa.2006.03.015. 
29. Germer K, Leonard M, Zhang X. RNA aptamers and their therapeutic and diagnostic applications. International Journal of Biochemistry and Molecular Biology. 2013; 4: 27-40.

30. Li N, Nguyen HH, Byrom M, Ellington AD. Inhibition of cell proliferation by na anti-EGFR aptamer PloS One. 2011; 6: e2029. https://doi.org/10.1371/journal.pone.0020299.

31. Burnett JC, Rossi JJ. RNA-based therapeutics: Current progress and future prospects. Chemistry \& Biology. 2012; 19: 60-71. https://doi.org/10.1016/j.chembiol.2011.12.008.

32. Ulrich H, Martins AH, Pesquero JB. RNA and DNA aptamers in cytomics analysis. Current Protocols in Cytometry. 2005; 7: 7.28. https://doi. org/10.1002/0471142956.cy0728s33.

33. Pendergrast PS, Marsh HN, Grate D, Healy JM, Stanton M. Nucleic acid aptamers for target validation and therapeutic applications. Journal of Biomolecular Techniques. 2005; 16: 224-34.

34. Mercier MC, Dontenwill M, Choulier L. Selection of nucleic acid aptamers targeting tumor cell-surface protein biomarkers. Cancers (Basel). 2017; 9: 69. https://doi. org/10.3390/cancers9060069.

35. Henry NL, Hayes DF. Cancer biomarkers. Molecular Oncology. 2012; 6: 140-46. https://doi.org/10.1016/j. molonc.2012.01.010.

36. Ellington AD, Szostak JW. Selection in vitro of singlestranded DNA molecules that fold into specific ligandbinding structures. Nature. 1992; 355: 850-52. https://doi. org/10.1038/355850a0.

37. Gedi V, Kim YP. Detection and characterization of cancer cells and pathogenic bacteria using aptamer-based nanoconjugates. Sensors. 2014; 14: 18302-27. https://doi. org/10.3390/s141018302.

38. Xi Z, Huang R, Deng Y, He N. Progress in selection and biomedical applications of aptamers. Journal of Biomedical Nanotechnology. 2014; 10: 3043-62. https:// doi.org/10.1166/jbn.2014.1979.

39. Chen H, Yuan CH, Yang YF, Yin CQ, Guan Q, Wang FB, Tu JC. Subtractive Cell-Selex selection of DNA aptamers binding specifically and selectively to hepatocellular carcinoma cells with high metastatic potential. BioMed Research International. 2016; 2016: 5735869. https://doi. org/10.1155/2016/5735869.

40. Quang NN, Miodek A, Cibie A, Ducongé F. Selection of aptamers against whole living cells: From CellSelex to identification of biomarkers. Methods in Molecular Biology. 2017; 1575: 253-72. https://doi. org/10.1007/978-1-4939-6857-2_16.

41. Weng CH, Hsieh IS, Hung LY, Lin HI, Shiesh SC, Chen YL, Lee GB. An automatic microfluidic system for rapid screening of cancer stem-like cell-specific aptamers. Microfluidics and Nanofluidics. 2012; 14: 753-65. https:// doi.org/10.1007/s10404-012-1095-3.
42. Hung LY, Wang CH, Hsu KF, Chou CY, Lee GB. An on-chip Cell-Selex process for automatic selection of high-affinity aptamers specific to different histologically classified ovarian cancer cells. Lab on a chip. 2014; 14 : 4017-28. https://doi.org/10.1039/c4lc00587b.

43. Hung LY, Wang CH, Che YJ, Fu CY, Chang HY, Wang K, Lee GB. Screening of aptamers specific to colorectal cancer cells and stem cells by utilizing on-chip Cell-Selex. Scientific Reports. 2015; 5: 10326. https://doi.org/10.1038/ srep10326.

44. Takahashi M, Sakota E, Nakamura Y. The efficient cellselex strategy, iCell-Selex, using isogenic cell lines for selection and counter-selection to generate rna aptamers to cell surface proteins. Biochimie. 2016; 131: 77-84. https:// doi.org/10.1016/j.biochi.2016.09.018.

45. Zamay TN, Zamay GS, Kolovskaya OS, Zukov RA, Petrova MM, Gargaun A, Berezovski MV, Kichkailo AS. Current and prospective protein biomarkers of lung cancer. Cancers (Basel). 2017; 13:9. https://doi.org/10.3390/ cancers9110155.

46. Daniels DA, Chen H, Hicke BJ, Swiderek KM, Gold L. A tenascin-c aptamer identified by tumor Cell Selex: Systematic evolution of ligands by exponential enrichment. Proceedings of the National Academy of Sciences of the United States of America. 2003; 100: 15416-21. https://doi. org/10.1073/pnas.2136683100.

47. Wu X, Zhao Z, Bai H, Fu T, Yang C, Hu X, Liu Q, Champanhac C, Teng IT, Ye M, Tan W. DNA aptamer selected against pancreatic ductal adenocarcinoma for in vivo imaging and clinical tissue recognition. Theranostics. 2015; 5: 985-94. https://doi.org/10.7150/thno.11938.

48. Champanhac C, Teng IT, Cansiz S, Zhang L, Wu X, Zhoa Z, Fu T, Tan W. Development of a panel of DNA aptamers with high affinity for pancreatic ductal adenocarcinoma. Scientific Reports. 2015; 5: 16788. https://doi.org/10.1038/ srep16788.

49. Kim YJ, Lee HS, Jung DE, Kim JM, Song SY. The DNA aptamer binds stemness-enriched cancer cells in pancreatic cancer. Journal of Molecular Recognition. 2017; 30. https:// doi.org/10.1002/jmr.2591.

50. Xu J, Teng IT, Zhang L, Delgado S, Champanhac C, Cansiz S, Wu C, Shan H, Tan W. Molecular recognition of human liver cancer cells using DNA aptamers generated via Cell-Selex. PloS One. 2015; 10: e0125863. https://doi. org/10.1371/journal.pone.0125863.

51. Tang Z, Shangguan D, Wang K, Shi H, Sefah K, Mallikratchy P, Chen HW, Li Y, Tan W. Selection of aptamers for molecular recognition and characterization of cancer cells. Analytical Chemistry. 2007; 79: 4900-07. https://doi.org/10.1021/ac070189y.

52. Ninomiya K, Kaneda K, Kawashima S, Miyachi Y, Ogino C, Shimizu N. Cell-SELEX based selection and characterization of DNA aptamer recognizing human hepatocarcinoma. Bioorganic \& Medicinal Chemistry 
Letters. 2013; 15:1797-02. https://doi.org/ 10.1016/j. bmcl.2013.01.040.

53. Civit L, Taghdisi SM, Jonczyk A, Haßel SK, Gröber C, Blank M, Stunden HJ, Beyer M, Schultze J, Latz E, Mayer G. Systematic evaluation of Cell-SELEX enriched aptamers binding to breast cancer cells. Biochimie. 2018; 145:53-62. https://doi.org/10.1016/j.biochi.2017.10.007.

54. Wang J, Yuan R, Song W, Sun J, Liu D, Li Z. PD-1, PD-L1 (B7-H1) and Tumor-Site Immune modulation therapy: The historical perspective. Journal of Hematology \& Oncology. 2017; 10: 34. https://doi.org/10.1186/s13045-017-0403-5.

55. Avci-Adali M, Metzger M, Perle N, Ziemer G, Wendel HP. Pitfalls of cell-systematic evolution of ligands by exponential enrichment (Selex): Existing dead cells during in vitro selection anticipate the enrichment of specific aptamers. Oligonucleotides. 2010; 20: 317-23. https://doi. org/10.1089/oli.2010.0253.

56. Bayrac AT, Sefah K, Parekh P, Bayrac C, Gulbakan B, Oktem HA, Tan W. in vitro selection of DNA aptamers to glioblastoma multiforme. ACS Chemical Neuroscience. 2011; 2: 175-81. https://doi.org/10.1021/cn100114k.

57. Kang D, Wang J, Zhang W, Song Y, Li X, Zou Y, Zhu M, Zhu Z, Chen F, Yang CJ. Selection of DNA aptamers against glioblastoma cells with high affinity and specificity. PloS One. 2012; 7: e42731. https://doi.org/10.1371/journal. pone.0042731.

58. Kim Y, Wu Q, Hamerlik P, Hitomi M, Sloan AE, Barnett GH, Weil RJ, Leahy P, Hjelmeland AB, Rich JN. Aptamer identification of brain tumor-initiating cells. Cancer Research. 2013; 73: 4923-36. https://doi.org/10.1158/00085472.CAN-12-4556.

59. Wu X, Liang H, Tang Y, Yuan C, Li S, Li X, Li G, Shi Y, Zhang X. Cell-Selex aptamer for highly specific radionuclide molecular imaging of glioblastoma in vivo. PloS One. 2014; 9: e90752. https://doi.org/10.1371/journal. pone.0090752.

60. Wu Q, Wu L, Wang Y, Zhu Z, Song Y, Tan Y, Wang XF, Li J, Kang D, Yang CJ. Evolution of DNA aptamers for malignant brain tumor gliosarcoma cell recognition and clinical tissue imaging. Biosensors \& bioelectronics. 2016; 80: 1-8. https://doi.org/10.1016/j.bios.2016.01.031.

61. Cerchia L, Esposito CL, Jacobs AH, Tavitian B, de Franciscis V. Differential Selex in human glioma cell lines. PloS one. 2009; 4: e7971. https://doi.org/10.1371/journal. pone.0007971.

62. Zhang K, Sefah K, Tang L, Zhao Z, Zhu G, Ye M, Sun W, Goodison S, Tan W. Novel aptamer developed for breast cancer cell internalization. ChemMedChem. 2012; 7: 79-84. https://doi.org/10.1002/cmdc.201100457.

63. Lu M, Zhou L, Zheng X, Quan Y, Wang X, Zhou X, Ren J. A novel molecular marker of breast cancer stem cells identified by Cell-Selex method. Cancer biomarkers: section A of Disease markers. 2015; 15: 163-70. https:// doi.org/10.3233/CBM-140450.
64. Moosavian SA, Jaafari MR, Taghdisi SM, Mosaffa F, Badiee A, Abnous K. Development of rna aptamers as molecular probes for her2+ breast cancer study using CellSelex. Iranian Journal of Basic Medical Sciences. 2015; 18 : 576-86. https://doi.org/10.22038/ijbms.2015.4532.

65. Chandrasekaran R, Lee AS, Yap LW, Jans DA, Wagstaff KM, Cheng W. Tumor cell-specific photothermal killing by selex-derived DNA aptamer-targeted gold nanorods. Nanoscale. 2016; 8: 187-96. https://doi.org/10.1039/ c5nr07831h.

66. Shi H, Tang Z, Kim Y, Nie H, Huang YF, He X, Deng K, Wang K, Tan W. in vivo fluorescence imaging of tumors using molecular aptamers generated by Cell-Selex. Chemistry - an Asian Journal. 2010; 5: 2209-13. https:// doi.org/10.1002/asia.201000242.

67. Jia W, Ren C, Wang L, Zhu B, Jia W, Gao M, Zeng F, Zeng L, Xia X, Zhang X, Fu T, Li S, Du C, et al. CD109 is identified as a potential nasopharyngeal carcinoma biomarker using aptamer selected by Cell-Selex. Oncotarget. 2016; 7: 55328-42. https://doi.org/10.18632/ oncotarget.10530.

68. Chen HW, Medley CD, Sefah K, Shangguan D, Tang Z, Meng L, Smith JE, Tan W. Molecular recognition of smallcell lung cancer cells using aptamers. ChemMedChem 2008. 3: 991-01. https://doi.org/10.1002/cmdc.200800030.

69. Kunii T, Ogura S, Mie M, Kobatake E. Selection of DNA aptamers recognizing small cell lung cancer using living Cell-Celex. The Analyst. 2011; 136: 1310-12. https://doi. org/10.1039/c0an00962h.

70. Shangguan D, Meng L, Cao ZC, Xiao Z, Fang X, Li Y, Cardona D, Witek RP, Liu C, Tan W. Identification of liver cancer-specific aptamers using whole live cells. Analytical Chemistry. 2008; 80: 721-28. https://doi.org/10.1021/ ac701962v.

71. Ninomiya K, Kaneda K, Kawashima S, Miyachi Y, Ogino C, Shimizu N. Cell-Selex based selection and characterization of DNA aptamer recognizing human hepatocarcinoma. Bioorganic \& Medicinal Chemistry Letters. 2013; 23: 1797-02. https://doi.org/10.1016/j.bmcl.2013.01.040.

72. Wang FB, Rong Y, Fang M, Yuan JP, Peng CW, Liu SP, Li Y. Recognition and capture of metastatic hepatocellular carcinoma cells using aptamer-conjugated quantum dots and magnetic particles. Biomaterials. 2013; 34: 3816-27. https://doi.org/10.1016/j.biomaterials.2013.02.018.

73. Rong Y, Chen H, Zhou XF, Yin CQ, Wang BC, Peng CW, Liu SP, Wang FB. Identification of an aptamer through whole Cell-Selex for targeting high metastatic liver cancers. Oncotarget. 2016; 7: 8282-94. https://doi.org/10.18632/ oncotarget.6988.

74. Wan J, Ye L, Yang X, Guo Q, Wang K, Huang Z, Tan Y, Yuan B, Xie Q. Cell-Selex based selection and optimization of DNA aptamers for specific recognition of human cholangiocarcinoma qbc-939 cells. The Analyst. 2015; 140: 5992-97. https://doi.org/10.1039/c5an01055a. 
75. Cao HY, Yuan AH, Shi XS, Chen W, Miao Y. Evolution of a gastric carcinoma cell-specific DNA aptamer by live cellselex. Oncology Reports. 2014; 32: 2054-60. https://doi. org/10.3892/or.2014.3411.

76. Van SD, López-Colón D, Sefah K, Sutphen R, Jimenez E, Tan W. Study of the molecular recognition of aptamers selected through ovarian cancer cell-selex. PloS One. 2010; 5: e13770. https://doi.org/10.1371/journal.pone.0013770.

77. Benedetto G, Hamp TJ, Wesselman PJ, Richardson C. Identification of epithelial ovarian tumor-specific aptamers. Nucleic acid therapeutics. 2015; 25: 162-72. https://doi. org/10.1089/nat.2014.0522.

78. Sefah K, Meng L, Lopez-Colon D, Jimenez E, Liu C, Tan W. DNA aptamers as molecular probes for colorectal cancer study. PloS One. 2010; 5: e14269. https://doi.org/10.1371/ journal.pone.0014269.

79. Li WM, Bing T, Wei JY, Chen ZZ, Shangguan DH, Fang J. Cell-selex-based selection of aptamers that recognize distinct targets on metastatic colorectal cancer cells. Biomaterials. 2014; 35: 6998-07. https://doi.org/10.1016/j. biomaterials.2014.04.112.

80. Li X, An Y, Jin J, Zhu Z, Hao L, Liu L, Shi Y, Fan D, Ji T, Yang CJ. Evolution of DNA aptamers through in vitro metastatic-cell-based systematic evolution of ligands by exponential enrichment for metastatic cancer recognition and imaging. Analytical Chemistry. 2015; 87: 4941-48. https://doi.org/10.1021/acs.analchem.5b00637.

81. Wang Y, Luo Y, Bing T, Chen Z, Lu M, Zhang N, Shangguan D, Gao X. DNA aptamer evolved by cellselex for recognition of prostate cancer. PLoS One. 2014; 9: e100243. https://doi.org/10.1371/journal. pone. 0100243 .

82. Almasi F, Gargari SLM, Bitaraf F, Rasoulinejad S. Development of a single stranded DNA aptamer as a molecular probe for lncap cells using cell-selex. Avicenna Journal of Medical Biotechnology. 2016; 8: 104-11.

83. Souza AG, Marangoni K, Fujimura PT, Alves PT, Silva MJ, Bastos VA, Goulart LR, Goulart VA. 3d cellselex: Development of RNA aptamers as molecular probes for pc-3 tumor cell line. Experimental Cell Research. 2016; 341: 147-56. https://doi.org/10.1016/j. yexcr.2016.01.015.

84. Wang H, Liang J, Ma Y, Sun B, Li X, Wei Y, Fu G, Li $\mathrm{M}, \mathrm{Xia}$ W. Identification of a novel molecular probe for recognition of human osteosarcoma cell using the cell-selex method. International Journal of Clinical and Experimental Medicine. 2015; 8: 18151-57.

85. Song S, Wang L, Li J, Fan C, Zhao J. Aptamer-based biosensors. Trends in Analytical Chemistry. 2008; 27: 108 17. https://doi.org/10.1016/j.trac.2007.12.004.

86. Zhu H, Li J, Zhang XB, Ye M, Tan W. Nucleic acid aptamer-mediated drug delivery for targeted cancer therapy. ChemMedChem. 2015; 10: 39-45. https://doi.org/10.1002/ cmdc. 201402312 .
87. Xiao Z, Shangguan D, Cao Z, Fang X, Tan W. Cellspecific internalization study of an aptamer from whole cell selection. Chemistry. 2008; 14: 1769-75. https://doi. org/10.1002/chem.200701330.

88. Kopec KK, Bozyczko-Coyne D, Williams M. Target identification and validation in drug discovery. Biochemical Pharmacology. 2005; 69: 1133-39. https://doi.org/10.1016/j. bcp.2005.01.004.

89. Leach JC, Wang A, Ye K, Jin S. A RNA-DNA hybrid aptamer for nanoparticle-based prostate tumor targeted drug delivery. International Journal of Molecular Sciences. 2016; 17: 380. https://doi.org/10.3390/ijms17030380.

90. Li X, Zhou H, Yang L, Du G, Pai-Panandiker AS, Huang X, Yan B. Enhancement of cell recognition in vitro by dual-ligand cancer targeting gold nanoparticles. Biomaterials. 2011; 32: 2540-45. https://doi.org/10.1016/j. biomaterials.2010.12.031.

91. Feng C, Rui M, Shen H, Xin Y, Zhang J, Li J, Yue L, Lai $\mathrm{W}, \mathrm{Xu}$ X. Tumor-specific delivery of doxorubicin through conjugation of $\mathrm{pH}$-responsive peptide for overcoming drug resistance in cancer. International Journal of Pharmaceutics. 2017; 528: 322-33. https://doi.org/10.1016/j. ijpharm.2017.06.022.

92. Xiang D, Shigdar S, Qiao G, Wang T, Kouzani AZ, Zhou SF, Kong L, Li Y, Pu C, Duan W. Nucleic acid aptamerguided cancer therapeutics and diagnostics: the next generation of cancer medicine. Theranostics. 2015; 5: 23-42. https://doi.org/10.7150/thno.10202.

93. Fan YP, Liao JZ, Lu YQ, Tian DA, Ye F, Zhao PX, Xiang GY, Tang WX, He XX. Mir-375 and doxorubicin co-delivered by liposomes for combination therapy of hepatocellular carcinoma. Molecular Therapy. 2017; 7: 181-89. https://doi.org/10.1016/j.omtn.2017.03.010.

94. Octavia Y, Kararigas G, de Boer M, Chrifi I, Kietadisorn R, Swinnen M, Duimel H, Verheyen FK, Brandt MM, Fliegner D, Cheng C, Janssens S, Duncker DJ, et al. Folic acid reduces doxorubicin-induced cardiomyopathy by modulating endothelial nitric oxide synthase. J Cell Mol Med. 2017; 21: 3277-3287. https://doi.org/10.1111/ jcmm.13231.

95. Peng LH, Zhang YH, Han LJ, Zhang CZ, Wu JH, Wang XR, Gao JQ, Mao ZW. Cell membrane capsules for encapsulation of chemotherapeutic and cancer cell targeting in vivo. ACS Appl Mater Interfaces. 2015; 7: 18628-37. https://doi.org/10.1021/acsami.5b05065.

96. Sun $\mathrm{H}, \mathrm{Zhu} \mathrm{X}, \mathrm{Lu} \mathrm{PY}$, Rosato RR, Tan W, Zu Y. Oligonucleotide aptamers: new tools for targeted cancer therapy. Mol Ther Nucleic Acids. 2014; 3: e182. https://doi. org/10.1038/mtna.2014.32.

97. Bates PJ, Reyes-Reyes EM, Malik MT, Murphy EM, O'Toole MG, Trent JO. G-quadruplex oligonucleotide AS1411 as a cancer-targeting agent: uses and mechanisms. Biochim Biophys Acta. 2017; 1861: 1414-28. https://doi. org/10.1016/j.bbagen.2016.12.015. 
98. Li X, Yu Y, Ji Q, Qiu L. Targeted delivery of anticancer drugs by aptamer AS1411 mediated pluronic f127/ cyclodextrin-linked polymer composite micelles. Nanomedicine. 2015; 11: 175-84. https://doi.org/10.1016/j. nano.2014.08.013.

99. Liao ZX, Chuang EY, Lin CC, Ho YC, Lin K.J, Cheng PY, Chen K.J, Wei HJ, Sung HW. An AS1411 aptamerconjugated liposomal system containing a bubblegenerating agent for tumor-specific chemotherapy that overcomes multidrug resistance. Journal of Controlled Release. 2015; 208: 42-51. https://doi.org/10.1016/j. jconrel.2015.01.032.

100. Trinh TL, Zhu G, Xiao X, Puszyk W, Sefah K, Wu Q, Tan W, Liu C. A synthetic aptamer-drug adduct for targeted liver cancer therapy. PloS One. 2015; 10: e0136673. https://doi. org/10.1371/journal.pone.0136673.

101. Atabia F, Gargarib SLM, Hashemic M, Yaghmaeia P. Doxorubicin loaded DNA aptamer linked myristilated chitosan nanogel for targeted drug delivery to prostate cancer. Iranian Journal of Pharmaceutical Research. 2017; 16:35-49.

102. Jing P, Cao S, Xiao S, Zhang X, Ke S, Ke F, Yu X, Wang L, Wang S, Luo Y, Zhong Z. Enhanced growth inhibition of prostate cancer in vitro and in vivo by a recombinant adenovirus-mediated dual-aptamer modified drug delivery system. Cancer Letters. 2016; 383: 230-42. https://doi. org/10.1016/j.canlet.2016.10.003.

103. Jeong H, Lee SH, Hwang Y, Yoo H, Jung H, Kim SH, Mok H. Multivalent aptamer-RNA conjugates for simple and efficient delivery of doxorubicin/siRNA into multidrugresistant cells. Macromolecular Bioscience. 2017; 17. https://doi.org/10.1002/mabi.201600343.

104. Sun P, Zhang N, Tang Y, Yang Y, Chu X, Zhao Y. Sl2b aptamer and folic acid dual-targeting DNA nanostructures for synergic biological effect with chemotherapy to combat colorectal cancer. International Journal of Nanomedicine. 2017; 12: 2657-72. https://doi.org/10.2147/IJN.S132929.

105. Sampath P, Rhines LD, DiMeco F, Tyler BM, Park MC, Brem H. Interstitial docetaxel (taxotere $(R)$ ): A novel treatment for experimental malignant glioma. Journal of Neuro-Oncology. 2006; 80: 9-17. https://doi.org/10.1007/ s11060-006-9159-4.

106. Gao H, Qian J, Cao S, Yang Z, Pang Z, Pan S, Fan L, Xi Z, Jiang X, Zhang Q. Precise glioma targeting of and penetration by aptamer and peptide dual-functioned nanoparticles. Biomaterials. 2012; 33: 5115-23. https://doi. org/10.1016/j.biomaterials.2012.03.058.

107. Zhao M, Liang C, Li A, Chang J, Wang H, Yan R, Zhang J, Tai J. Magnetic paclitaxel nanoparticles inhibit glioma growth and improve the survival of rats bearing glioma xenografts. Anticancer Research. 2010; 30: 2217-23.

108. Taghavi S, Ramezani M, Alibolandi M, Abnous K, Taghdisi SM. Chitosan-modified plga nanoparticles tagged with $5 \operatorname{tr} 1$ aptamer for in vivo tumor-targeted drug delivery.
Cancer Letters. 2017; 400: 1-8. https://doi.org/10.1016/j. canlet.2017.04.008.

109. Ray P, Cheek MA, Sharaf ML, Li N, Ellington AD, Sullenger BA, Shaw BR, White RR. Aptamer-mediated delivery of chemotherapy to pancreatic cancer cells. Nucleic Acids Ther. 2012; 22: 295-05. https://doi.org/10.1089/ nat.2012.0353.

110. Zhao X, Lis JT, Shi H. A systematic study of the features critical for designing a high avidity multivalent aptamer. Nucleic Acids Ther. 2013; 23: 238-42. https://doi. org/10.1089/nat.2012.0410.

111. Lozano T, Soldevilla MM, Casares N, Villanueva H, Bendandi M, Lasarte JJ, Pastor F. Targeting inhibition of foxp3 by a cd28 2'-fluro oligonucleotide aptamer conjugated to p60-peptide enhances active cancer immunotherapy. Biomaterials. 2016; 91: 73-80. https://doi. org/10.1016/j.biomaterials.2016.03.007.

112. Bruno JG. Aptamer-biotin-streptavidin-c1q complexes can trigger the classical complement pathway to kill cancer cells. In Vitro Cell Dev Bio Anim. 2010; 46: 107-13. https:// doi.org/10.1007/s11626-009-9257-7.

113. Simpson TR, Li F, Montalvo-Ortiz W, Sepulveda MA, Bergerhoff K, Arce F, Roddie C, Henry JY, Yagita H, Wolchok JD, Peggs KS, Ravetch JV, Allison JP, et al. Fc-dependent depletion of tumor-infiltrating regulatory $t$ cells co-defines the efficacy of anti-ctla-4 therapy against melanoma. J Exp Med. 2013; 210: 1695-10. https://doi. org/10.1084/jem.20130579.

114. Freeman GJ, Long AJ, Iwai Y, Bourque K, Chernova T, Nishimura H, Fitz LJ, Malenkovich N, Okazaki T, Byrne MC, Horton HF, Fouser L, Carter L, et al. Engagement of the pd-1 immunoinhibitory receptor by a novel b7 family member leads to negative regulation of lymphocyte activation. J Exp Med. 2000; 192: 1027-24. https://doi. org/10.1084/jem.192.7.1027.

115. Finn OJ. Cancer immunology. N Engl J Med. 2008; 358: 2704-15. https://doi.org/10.1056/NEJMra072739.

116. Wagner LM, Adams VR. Targeting the pd-1 pathway in pediatric solid tumors and brain tumors. Onco Targets Ther. 2017; 10: 2097-06. https://doi.org/10.2147/OTT. S124008.

117. Laubli H, Balmelli C, Bossard M, Pfister O, Glatz K, Zippelius A. Acute heart failure due to autoimmune myocarditis under pembrolizumab treatment for metastatic melanoma. J Immunother Cancer. 2015; 3: 11. https://doi. org/10.1186/s40425-015-0057-1.

118. Johnson DB, Balko JM, Compton ML, Chalkias S, Gorham J, Xu Y, Hicks M, Puzanov I, Alexander MR, Bloomer TL, Becker J, Slosky DA, Phillips EJ, et al. Fulminant myocarditis with combination immune checkpoint blockade. N Engl J Med. 2016; 375: 1749-55. https://doi. org/10.1056/NEJMoa1609214.

119. Hia CPP. Immunosuppressive therapy in acute myocarditis: an 18 year systematic review. Archives of Disease in 
Childhood. 2004; 89: 580-84. https://doi.org/10.1136/ adc.2003.034686.

120. Cortes-Dericks L, Schmid RA. CD44 and its ligand hyaluronan as potential biomarkers in malignant pleural mesothelioma: evidence and perspectives. Respiratory Research. 2017; 18: 58. https://doi.org/10.1186/ s12931-017-0546-5.

121. Jimenez CR, Knol JC, Meijer GA, Fijneman RJ. Proteomics of colorectal cancer: overview of discovery studies and identification of commonly identified cancerassociated proteins and candidate crc serum markers. J Proteomics. 2010; 73: 1873-95. https://doi.org/10.1016/j. jprot.2010.06.004.

122. Phua LC, Chue XP, Koh PK, Cheah PY, Ho HK, Chan EC. Non-invasive fecal metabonomic detection of colorectal cancer. Cancer Biology \& Therapy. 2014; 15: 389-97. https://doi.org/10.4161/cbt.27625.

123. Holst S, Stavenhagen K, Balog CI, Koeleman CA, McDonnell LM, Mayboroda OA, Verhoeven A, Mesker WE, Tollenaar RA, Deelder AM, Wuhrer M. Investigations on aberrant glycosylation of glycosphingolipids in colorectal cancer tissues using liquid chromatography and matrix-assisted laser desorption time-of-flight mass spectrometry (maldi-tof-ms). Mol Cell Proteomics. 2013; 12: 3081-93. https://doi.org/10.1074/mcp.M113.030387.

124. Manna SK, Tanaka N, Krausz KW, Haznadar M, Xue X, Matsubara T, Bowman ED, Fearon ER, Harris CC, Shah YM, Gonzalez FJ. Biomarkers of coordinate metabolic reprogramming in colorectal tumors in mice and humans. Gastroenterology. 2014; 146: 1313-24. https://doi. org/10.1053/j.gastro.2014.01.017.

125. Tarhini AA, Edington H, Butterfield LH, Lin Y, Shuai Y, Tawbi H, Sander C, Yin Y, Holtzman M, Johnson J, Rao UN, Kirkwood JM. Immune monitoring of the circulation and the tumor microenvironment in patients with regionally advanced melanoma receiving neoadjuvant ipilimumab. PloS One. 2014; 9: e87705. https://doi.org/10.1371/journal. pone. 0087705 .

126. Maeda $H$. The enhanced permeability and retention (epr) effect in tumor vasculature: The key role of tumor-selective macromolecular drug targeting. Advances in Enzyme Regulation. 2001; 41: 189-07. https://doi.org/10.1016/ S0065-2571(00)00013-3.

127. Peer D, Karp JM, Hong S, Farokhzad OC, Margalit R, Langer R. Nanocarriers as an emerging platform for cancer therapy. Nature Nanotechnology. 2007; 2: 751-60. https:// doi.org/10.1038/nnano.2007.387.

128. Lammers T, Kiessling F, Hennink WE, Storm G. Drug targeting to tumors: Principles, pitfalls and (pre-) clinical progress. J Contr Rel. 2012; 161: 175-87. https://doi. org/10.1016/j.jconrel.2011.09.063.

129. Jain RK, Stylianopoulos T. Delivering nanomedicine to solid tumors. Nat Rev Clin Oncol. 2010; 7: 653-64. https:// doi.org/10.1038/nrclinonc.2010.139.
130. Carthew RW, Sontheimer EJ. Origins and mechanisms of miRNAs and siRNAs. Cell. 2009; 136: 642-55. https://doi. org/10.1016/j.cell.2009.01.035.

131. Arias JL, Clares B, Morales ME, Gallardo V, Ruiz MA. Lipid-based drug delivery systems for cancer treatment. Current Drug Targets. 2011; 12:1151-65. https://doi. org/10.2174/138945011795906570.

132. Berezhnoy A, Castro I, Levay A, Malek TR, Gilboa E. Aptamer-targeted inhibition of mTOR in T cells enhances antitumor immunity. The Journal of Clinical Investigation. 2014; 124: 188-97. https://doi.org/10.1172/JCI69856.

133. Dassie JP, Liu XY, Thomas GS, Whitaker RM, Thiel KW, Stockdale KR, Meyerholz DK, McCaffrey AP, McNamara JO 2nd, Giangrande PH. Systemic administration of optimized aptamer-siRNA chimeras promotes regression of PSMA-expressing tumors. Nature Biotechnology. 2009; 27 : 839-49. https://doi.org/10.1038/nbt.1560.

134. McNamara JO 2nd, Andrechek ER, Wang Y, Viles KD, Rempel RE, Gilboa E, Sullenger BA, Giangrande PH. Cell type-specific delivery of sirnas with aptamer-sirna chimeras. Nature Biotechnology. 2006; 24: 1005-15. https://doi.org/10.1038/nbt1223.

135. Lupold SE, Hicke BJ, Lin Y, Coffey DS. Identification and characterization of nuclease-stabilized RNA molecules that bind human prostate cancer cells via the prostate-specific membrane antigen. Cancer Research. 2002; 6: 4029-33.

136. Liu Z, Duan JH, Song YM, Ma J, Wang FD, Lu X, Yang XD. Novel HER2 aptamer selectively delivers cytotoxic drug to HER2-positive breast cancer cells in vitro. Journal of Translational Medicine. 2012; 10:148. https://doi. org/10.1186/1479-5876-10-148.

137. Thiel KK, Hernandez LI, Dassie JP, Thiel WH, Liu X, Stockdale KR, Rothman AM, Hernandez FJ, McNamara JO 2nd, Giangrande PH. Delivery of chemo-sensitizing siRNAs to HER2 ${ }^{+}$-breast cancer cells using RNA aptamers. Nucleic Acids Research. 2012; 40: 6319-37. https://doi. org/10.1093/nar/gks294.

138. AlShamaileh H, Wang T, Xiang D, Yin W, Tran PH, Barrero RA, Zhang PZ, Li Y, Kong L, Liu K, Zhou SF, Hou Y, Shigdar S. Aptamer-mediated survivin RNAi enables 5-fluorouracil to eliminate colorectal cancer stem cells. 2017; Sci Rep. 2017; 7: 5898. https://doi.org/10.1038/ s41598-017-05859-z.

139. Bahreyni A, Yazdian-Robati R, Hashemitabar S, Ramezani M, Ramezani P, Abnous K, Taghdisi SM. A new chemotherapy agent-free theranostic system composed of graphene oxide nano-complex and aptamers for treatment of cancer cells. International Journal of Pharmaceutics. 2017; 526: 391-99. https://doi.org/10.1016/j.ijpharm.2017.05.014.

140. Circu ML, Aw TY. Reactive oxygen species, cellular redox systems, and apoptosis. Free Radical Biology \& Medicine. 2010; 48: 749-62. https://doi.org/10.1016/j. freeradbiomed.2009.12.022. 
141. Esmaeili MA, Abagheri-Mahabadi N, Hashempour H, Farhadpour M, Gruber CW, Ghassempour A. Viola plant cyclotide vigno 5 induces mitochondria-mediated apoptosis via cytochrome c release and caspases activation in cervical cancer cells. Fitoterapia; 2016: 109: 162-68. https://doi. org/10.1016/j.fitote.2015.12.021.
142. Elmore S. Apoptosis: A review of programmed cell death. Toxicologic Pathology. 2007; 35: 495-16. https://doi. org/10.1080/01926230701320337.

143. Hori SI, Herrera A, Rossi JJ, Zhou J. Current advances in aptamers for cancer diagnosis and therapy. Cancers (Basel). 2018; 10:9. https://doi.org/10.3390/cancers10010009. 